\title{
The Apex of the Pechenegs' Political Importance
}

\subsection{Borders and Internal Territorial Divisions of the Newly-Created Patzinacia}

As a result of the events described in Chapter Three, the Pechenegs assumed control over vast stretches of the Black Sea steppe. We owe our knowledge of their move to a new homeland to Constantine Porphyrogenitus, who wrote in Chapter 37 of De administrando imperio:

Four tribes of the Pechenegs, that is to say, the thema of Kouartzitour and the thema of Syroukalpeï and the thema of Borotalmat and the thema of Boulatzopon, lie beyond the Dnieper river towards the eastern and northern parts that face Uzia and Chazaria and Alania and Cherson and the rest of the klimata. The other four tribes lie on this side of the Dnieper river, towards the western and northern parts, that is to say that the thema of Giazichopon is neighbour to Bulgaria, the thema of Kato Gyla is neighbour to Tourkia, the thema of Charaboï is neighbour to Rus', and the thema of Iabdiertim is neighbour to the tributary territories of the country of Rus', to the Oultines and Dervlenines and Lenzenines and the rest of the Slavs. Patzinacia is distant a five days journey from Uzia and Chazaria, a six days journey from Alania, a ten days journey from Mordia, one day's journey from Rus', a four days journey from Tourkia, half a day's journey from Bulgaria; to Cherson it is very near, and to Bosporus closer still. ${ }^{1}$

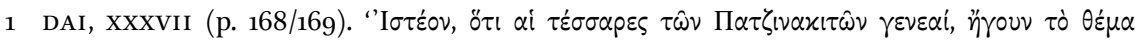

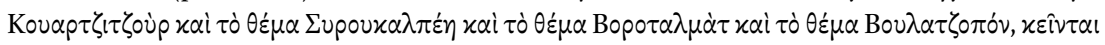

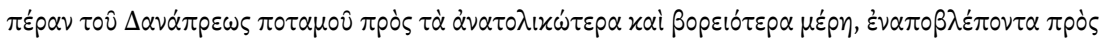

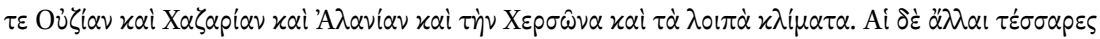

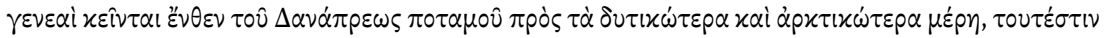

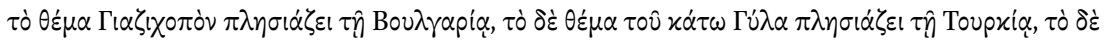

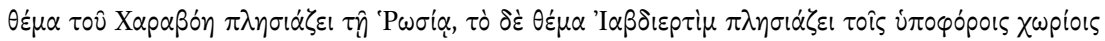

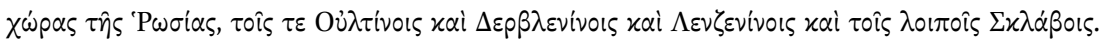

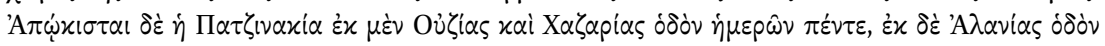

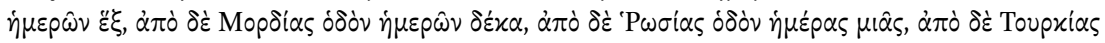

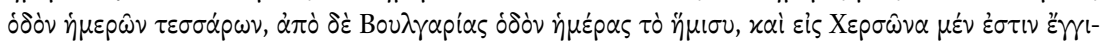

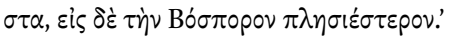

(C) ALEKSANDER PAROŃ AND INSTITUTE OF ARCHAEOLOGY AND ETHNOLOGY POLISH ACADEMY OF SCIENCES, 2021 | DOI:10.1163/9789004441095_007

This is an open access chapter distributed under the terms of the CC BY-NC-ND 4te licensender Paroń - 9789004441095 
In Chapter 42, the learned Basileus adds:

From the lower reaches of the Danube river, opposite to Distra, Patzinacia stretches along, and its inhabitants control the territory as far as Sarkel, the fortress of the Chazars $[\ldots] .^{2}$

A key issue and one that offers a starting point for our discussion in this chapter is the problem of the borders of Patzinacia. In light of the two above passages, the most obvious interpretation is that the newcomers occupied the area from the Lower Danube to the Don. This territory roughly corresponds to the former domain of the Magyars, called by them Etelköz. ${ }^{3}$ This information leads to the conclusion that the Pechenegs extended their rule over this area relatively quickly in the late 9 th or early 1oth century.

However, this interpretation has long been controversial. A number of primarily Bulgarian and Romanian researchers question the value of the written sources used to reconstruct the borders of the territory occupied by the Pechenegs at the turn of the 9 th and 1oth centuries. ${ }^{4}$ The information contained in De administrando imperio, especially Chapter 42 , is supposed to describe the state of political affairs at the time the work was written, i.e., the mid-1oth century. This suggests that the steppe peoples conquered the territories west of the Dniester as late as around $95^{\circ}$ or shortly before. Bulgarian scholars also refer to certain fragments of De administrando imperio that apparently indicate the existence of a Bulgarian state dominating the left bank of the Danube even in the times of Constantine Porphyrogenitus. In the initial part of Chapter Eight, we find a reference that some Pecheneg tribes supposedly inhabited some part of Bulgaria, located near the Dnieper, Dniester and 'the other rivers of those parts. ${ }^{5}$ This account clearly shows, however, that the part of Bulgaria across the Danube was already in the hands of the Pechenegs, so it is difficult to consider the passage as a decisive argument in this dispute. One can attempt on its basis to prove the existence of Bulgarian control over some part of the Black Sea steppe region, but not during the time De administrando imperio was

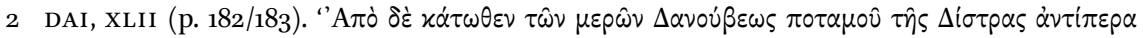

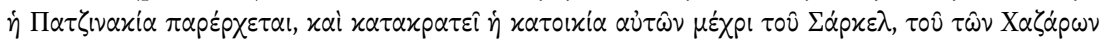

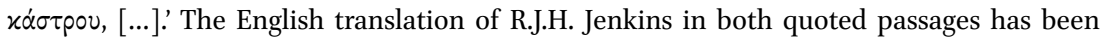
slightly modified.

3 DAI, XXXVII 68-71 (p. 170); XXXVIII 64-71 (p. 174); XL 23-25 (p. 176). Cf. Chapter 3 of the present book.

4 Diaconu 1970, 11-25; Bozhilov 1973, 37-62; Dimitrov 2011, 208-216; Cf. Mladjov 1998, 85-128.

5 DAI, VIII 5-7 (p. 54/55). Cf. Bozhilov 1973, 55-59; Mladjov 1998, 87; Dimitrov 2011, 209. 
written. In the following chapter, devoted to navigation along the trade route 'from the Varangians to the Greeks', there is a brief mention that the Rus' were no longer under any threat from the Pechenegs after passing by the island of St. Gregory situated on the Dnieper River. The nomads posed a danger to them again only in the vicinity of Sulina, the middle branch of the Danube Delta. ${ }^{6}$ This information was also the basis for speculation about the Bulgarians possessing territory across the Danube. It was assumed that since the Pechenegs could not reach the Rus' while sailing between the mouths of the Dnieper and the Danube, some part of the Black Sea coast and its interior must have been under the political control of Bulgarian groups situated between the two rivers. ${ }^{7}$ However, it is easy to agree with Dimitri Obolensky that the only conclusion that can be drawn from the above mention in De administrando imperio is that the Rus' sailed on the open sea between the mouth of the Dnieper and Sulina, where they were safe from attack by the Pechenegs. ${ }^{8}$

The possibility of Bulgarian dominion over areas north of the Danube in the 1oth century is also supposedly proven by a passage in John Skylitzes' chronicle in which the author describes events accompanying the restoration of the Byzantine border on the lower Danube. Emperor John I Tzimiskes is said to have met with the commanders of border strongholds to accept tribute from them. It is rightly assumed that these were the commanders of Bulgarian fortifications, which the chronicler describes as 'Constantia and the other fortresses established beyond the Danube. ${ }^{9}$ However, this passage raises serious doubts. In Skylitzes' wording there is clear logical conjunctive link between 'Constantia and the other fortresses', which leads us to conclude that they should be located on the same, north bank of the river. The problem here is that Romanian researchers have located the above-mentioned fortification in Dobrudja, south of the Danube. ${ }^{10}$ This renders interpretation of Skylitzes' passage problematic. Finally, we should note that the existence of Bulgarian fortresses in the foreground of the Danube has not been archaeologically

\footnotetext{
6 DAI, IX 78-79, 93-98 (pp. 6o-63).

7 Dimitrov 2011, 208.

$8 \quad$ DAI-Com., 56 .

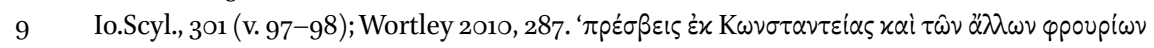

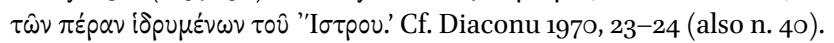

10 Diaconu 1970, 24 (also n. 40); Madgearu 2013, 32-35. The latter assumes that the quoted passage refers to some strongholds located in the foreland of Dorostolon (Dristra), which would mean that they would be located at the borders of the Pecheneg sphere of influence described by Constantine Porphyrogenitus.
} 
confirmed. ${ }^{11}$ The absence of the Bulgarian centres of power in this region also seem to be very revealing. ${ }^{12}$

One last argument for a Bulgarian presence is the creation of a military

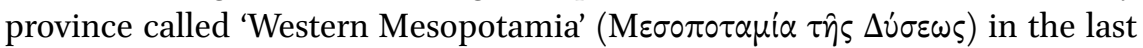
quarter of the 1oth century, after the restoration of the Byzantine border on the Danube. On the mere basis of this fact, it has been assumed that it was established in formerly Bulgarian territory, which was probably located north of the lower reaches of the Danube. Today, however, the dominant view seems to be that this 'interfluve' was located in northern Dobrudja. ${ }^{13}$

A review of the interpretations above seems to indicate that the information from available narrative sources do not provide grounds for questioning the notion of Pecheneg dominance over the Black Sea steppe from the Don to the Lower Danube at the turn of the gth and 1oth centuries.

A more complicated picture is drawn by analyses of archaeological data. It has long been noted that the oldest archaeological sites possibly associated with the Pechenegs, of which the vast majority are burial sites, are located between the Prut and Dniester Rivers and date back to the latter half of the 1oth century. ${ }^{14} \mathrm{~A}$ characteristic feature of these sites is that they often occur in the vicinity of findings attributed to the agricultural population of the Dridu culture. Only in the early years of the following century did the settled population begin to gradually withdraw to mountain and upland areas, less typical of the nomads or simply more difficult for them to access. ${ }^{15}$ More to the west, in

11 The only fortress that can be associated with the Bulgarian state is the Slon fortification, located on the southern ridge of the Carpathian Mountains and abandoned in the first decades of the 1oth century. Cf. Ciupercă 2010, 281. In addition, the Giurgiu fortification, dating back to the late 1oth century, is located west of Dristra. Cf. Ioaniţă 2005, 49-54, 174 (fig. 2).

12 It is worth mentioning that fortifications enable effective control of a particular region. Movable remains of a people's presence, although they undoubtedly indicate a cultural influence, cannot be treated as evidence of political domination. Cf. Comşa 196o, 395422. Comşa assumes that findings from the northern bank of the Danube, dating from the 9 th or 1oth century show similar features to those from the south (Pliska, Madara, Preslav, Rasgrad, Popina, etc.), which proves the political control Bulgarian rulers exerted over this region, and which supposedly only ceased during the reign of Tsar Peter, around 95o.

13 Madgearu 1999, 421; 2013, 41-42. The 'Western Mesopotamia' thema is considered to have been located between the Danube, the Caraș valley and the Black Sea.

14 Diaconu 1970, 15-17; Bálint 1989, 142, 144; Ioaniţă 2004, 469 (21 burials, which the researcher dates to the 11th or 12th centuries and considers to be of Pecheneg or Cuman origin); 2010, 115-134; Postică 2007, 91.

15 Diaconu 1970, 37-48; 1975, 237; Spinei 1975, 274; 1986, 103. Cf. Chapter 6.2 of the present book. 
the area of the Bărăgan Plain (eastern Wallachia), Pecheneg burial sites are much less frequent and usually date back to the 11th century. Researchers working in the area between the Lower Danube and the southern arch of the Carpathians point to a clear drop in the number of open agricultural settlements during that century. This phenomenon persists in the following centuries. ${ }^{16}$

The findings presented above are very important, but it is essential to clarify what they actually prove, and, to be more precise, whether they indicate the increasing presence of nomads in areas west of the Dniester, and whether they might also indicate the nature of the process by which this political penetration took place. It is difficult to question the first point. The Pechenegs, who in the late 1oth century most likely began to withdraw under pressure from the Uzes, most likely lost some of their encampment areas east of the Dnieper River. As a result, a part of this people was forced to move onto the steppe of the Prut-Dniester interfluve, which in turn led to the exodus of the local agricultural population. ${ }^{17}$ In terms of the Pechenegs' political influence, the situation is somewhat different. Available comparative material provides a sufficient basis for concluding that the introduction of nomad political domination over such settled communities did not necessarily result in a disturbance in the lives of the latter, as confirmed by archaeological material. It was usually in the interest of the nomads to subordinate the agricultural population and take advantage of its labour, and never to destroy these communities without legitimate cause. It is worth noting that the Avar Khaganate, the heart of which comprised the river valley of the Tisza and the central Danube, had under its control numerous Slavic and Germanic (mainly Gepids) communities, and even a post-Roman population. ${ }^{18}$ The existence of an enclave of such a group is confirmed by findings from the area south of Lake Balaton. ${ }^{19}$

This same phenomenon is even more evident in the case of the Khazar Empire. In addition to a heartland centre located on the steppe between the Caucasus, Caspian Sea, Don and lower Volga and inhabited by the state's political elites, the imperial rulers controlled huge stretches of land that transcended the borders of the steppe and forest steppe and was inhabited by a very culturally diverse population. ${ }^{20}$ Finally, there is the example of 'Old Scythia' or, following the classification of Anatoly Khazanov, ${ }^{21}$ the Second Scythian

\footnotetext{
16 Comşa 196o, 422; Ioaniţă 2005, 110; Spinei 2009, 105-106, 198.

17 Cf. Chapter 6.1 of the present book.

18 Szymański 1979, 52-63; Pohl 1988, 225-236; Vida 20o8, 13-46.

19 Müller 1992, 278-281; Heinrich-Tamáska 2012, 228-232.

20 Dunlop 1954, 140-142; Noonan 2001, 77. Cf. also Chapter 2 of the present book.

21 Khazanov 1978b, 427-429.
} 
Kingdom, which stretched across the Black Sea steppe, between the Don and the Danube. Its political centre, inhabited by the Royal Scythians, was located on the steppe to the east of the Dnieper-Borysthenes, while the territories to the west of the river were occupied by agricultural communities. ${ }^{22}$

This last analogy is quite revealing. It seems to clarify uncertainties about the Pechenegs' abilities to the quickly bring areas west of the Dniester River under their control. They were most likely mainly based more to the east, but this does not change the fact that relatively early on, probably in the early 1oth century, they extended their control west all the way to Dristra, onto the Bărăgan Plain. They did all the more easily because the only political power capable of stopping them at the turn of the gth and 1oth centuries was Bulgaria, which under Simeon's rule (893-927) was engaged in a fierce rivalry with the Byzantine Empire, which obviously had to limit its activity on the Black Sea steppe.

The Pechenegs thus controlled wide stretches of land from the lower Don and the Khazar stronghold of Sarkel to the lower Danube. The southern border of their sphere of influence ran from the mouth of the Don along the northern shores of the Sea of Azov and the Black Sea to the Danube Delta, all the way to Dristra. It is not clear however whether the areas around the estuaries of the Don, Dnieper, Dniester and Danube were also controlled by the Pechenegs. ${ }^{23}$ It is believed that the island of St. Eterius, located at the mouth of Dnieper, was in the hands of the Byzantine Empire. ${ }^{24}$ In the case of the Danube, the Pechenegs had access to Sulina, the middle branch of its mouth. There is also contradictory information about the presence of these nomads in the Crimea. Their permanent settlement in its northern, steppe regions seem to be confirmed by De administrando imperio (passage cited above). A reference in Chapter 42, however, seems to suggest another interpretation. Constantine VII mentions here that the ancients (oi $\pi \alpha \lambda \alpha 10^{i}$ ) dug a canal across the Isthmus of Perekop, connecting Crimea with the continent. However, as time passed, the canal they created became filled with silt, and a large forest grew in its place, through which two roads led to the peninsula. These were supposedly used by the Pechenegs when they travelled to Kherson or the Bosporus. ${ }^{25}$ The last statement would suggest that northern Crimea was not (at least in the time of Constantine VII) yet inhabited by them. ${ }^{26}$ This troublesome contradiction

\footnotetext{
22 Cf. Chapter 2 of the present book.

23 Cf. Shcherbak 1959, 368.

24 DAI-Com., 56.

25 DAI, XLII 78-83 (p. 186).

26 Cf. Romashov 1999, 26.
} 
seems impossible to solve. We can only posit that the Pechenegs may have controlled northern Crimea, but may have also used it as an occasional site for their nomadic settlements. ${ }^{27}$ The western border of Patzinacia was most likely the arching belt of the Carpathians, in the east the Pechenegs' political influence most likely reached the Don, though here too archaeological materials complicate the conclusions we can draw from the account of Constantine Porphyrogenitus. Communities associated with the Saltovo-Maiaki culture (connected with the Khazar Khaganate) in the forest steppe interfluve of the middle Don and upper Donets survived the migration of the Pechenegs. Their destruction came only in the latter half of the 1oth century and was probably brought about not by the Pechenegs, but by the Rus.28 Some researchers also assume that the Black Bulgars lived on the northern shores of the Sea of Azov as early as at the early 1oth century. Although they later moved to the north in the mid-1oth century, their migration was gradual, so it did not represent a sudden flight from the Pechenegs. ${ }^{29}$ In order to reconcile the image created by advancements in archaeological research with the data from written sources, it should be recognized that the situation at the eastern end of the Pechenegs' territory could have been analogous to that on the western end, i.e., the political expansion of the nomads may not have been accompanied by the expansion of their settlements. In some areas between the Don and Donets, cohabitation between the Saltovo-Maiaki population and nomads could have occurred..$^{30}$ The close proximity of the still strong Khazar Khaganate could also have led to the establishment of a division in terms of political influence, a sort of Khazar-Pecheneg condominium, especially in the forest steppe part of this area.

The northern border of Patzinacia is the most difficult to outline. Petr Golubovskii was among the first to express the seemingly accurate view that the border was really never clearly delineated during the Pechenegs' presence on the Black Sea steppe. ${ }^{31}$ This could have been a frequent cause of tensions between the nomads and their settled neighbours. ${ }^{32}$ Since the natural environment of the nomads were steppe and forest steppe areas, their borders can be used to determine the furthest extent of their political domination, which most

\footnotetext{
27 Contrary to the account of Constantine Porphyrogenitus, the Pecheneg burials found in this area seem to indicate this. Pletneva 1958, 154 (map); Garustovich, Ivanov 2001, 128-9 (map 1); Makarova, Aibabin 2003, 74-81.

28 Zhivkov 2015, 132-133.

29 Artamonov 1962, 358; Zhivkov 2015, 128-129.

30 Mikheev 1985, 99; Zhivkov 2015, 219.

31 Golubovskii 1884, 70; Cf. Shcherbak 1959, 375.

32 Noonan 1992, 303. Cf. also Chapter 4.4 of the present book.
} 
likely was the northern end of the forest steppe zone. This border is currently drawn along the following line: Rivne-Zhitomir-Kiev-Konotop-Briansk-Tula. ${ }^{33}$ Topomastic data seems to indicate a Pecheneg presence as far as the vicinity of today's Kaluga, ${ }^{34}$ as well as Przemyśl, Sokal, and Volodimir-Volins'kii, and thus crossing the boundaries of the forest zone. ${ }^{35}$ The last cases, however, most likely represent instances of late settlement, when the Pechenegs had already lost their independence and were dispersed. The northern boundary of the Pecheneg sphere of influence was probably marked by the territories occupied by the young Rus' state and the East Slavic tribes subordinate to it. It is assumed that the Severians and Viatichi, who inhabited areas east of the Dnieper River, were forced to abandon their southernmost settlements. The Viatichi left an area on the upper Don that extended to the mouth of the Voronezh River. The Severians moved across the Sula River. The reason for both migrations was most likely the expansion of the Pechenegs. ${ }^{36}$ The Uliches and Tiverians shared a similar fate. The former originally inhabited the territory on the right bank of the Dnieper River, from the rapids to the Tiasmin River, the settlements of the latter stretched between the Dniester, Prut and Danube to the Black Sea. As a result of the Pechenegs' arrival, the main centres of Ulich settlement moved to areas by the Stugna River, in the immediate vicinity of Kiev. Today it is known as the site of the Peresechen' stronghold. The Tiverians moved north of the estuary of the Reut, a right-bank tributary of the Dniester. ${ }^{37}$ Therefore, based on data on the migration of East Slavic tribes, we can assume that the territory controlled by the Pechenegs in the north-east

33 Szymański 199o, 475. Cf. Chapter 1 of the present book.

34 Shcherbak 1959, 375 .

35 Kucharski, Lewicki 1934, 45-46; Rasovskii 1933, 7; Kuczyński 1965, 42; 1954-56, 274.

36 Szymański 199o, 48o, 484; 1973, 46; 1977, 412-413; Łowmiański 1975a, 177; Sedov 1982, 142; Timoshchuk 1995, 185; Zhivkov 2015, 219. Researchers, however, suggest different dates for when the Slavs supposedly left their homes by the Don River. Wojciech Szymański assumed that this had already happened by the end of the 9th century and connected this fact with the migration of the Pechenegs (especially in the case of the Viatichi). In the case of the Severians, Szymański suggested that the collapse of the 'Romny' culture associated with them occurred only in the 1oth century and that this process was linked to the collapse of the Khazar Khaganate. Henryk Łowmiański dates the collapse of the Severian settlement process to the last decades of the 1oth century and claims it was clearly connected with Pecheneg aggression against Rus'. Valentin Sedov makes similar points, though he places stronger emphasis on archaeological premises. Timoshchuk, meanwhile, dates the abandonment of the Severian settlements to the end of the 9 th century.

37 Szymański 1973, 47; 199o, 478-479; Sedov 1982, 130, 132; Romashov 1999, 30-31; Spinei 2009, 87 (also for further literature on the subject). Spinei locates the Uliches a little further south, in the area of the central basin of the Boh River. 
probably reached the confluence of the Voronezh and Don Rivers. Its border then moved westwards through areas around the sources of the Donets and Vorskla, up to Sula, which it probably never crossed. On the right bank of the Dnieper, the Pechenegs were originally separated from Kiev by Ulich settlements, but in the mid-1oth century, when due to a fierce rivalry with the Rurik dynasty, they moved onto the basin of the upper Boh and Dniester, ${ }^{38}$ while the territory controlled by the nomads most likely moved closer to the capital. Next, the border of the Pechenegs' lands crossed the middle course of the Boh, the Dniester south of the mouth of the Reut, and the Prut and Siret, also in the middle course of both rivers, ultimately reaching the Carpathian Mountains.

This is what the borders of Patzinacia looked like; its internal divisions between the eight tribes mentioned by Constantine Porphyrogenitus is a separate issue. There is no certainty as to when the boundaries of the territories occupied by Pechenegs were finally established. It can only be assumed that this happened shortly after the conquest of Etelköz. The most successful proposal thus far for establishing the location of the Pecheneg tribes has been that presented by György Györffy. ${ }^{39}$ The Hungarian scholar based his conclusions not only on the contents of Chapter 37 of De administrando imperio cited above, but also on information from other parts of this work concerning how contacts with the Pechenegs were established. Constantine Porphyrogenitus claims that the Pechenegs could be found most often in the vicinity of rivers, because this is where they camped. ${ }^{40}$ Györffy also refers to observations made by William of Rubruck and John of Pian de Carpini, according to which Mongolian chiefs, who lived a nomadic life on the Black Sea steppe several hundred years after the departure of the Pechenegs, would also move in an oscillating pattern of movement along the right or left bank of a river between their summer and winter encampment sites. The latter were located not far from the sea, and the former in the north, deep in the forest steppe. ${ }^{41}$

Therefore, taking into account all the factors described above, Györffy assumes that the Giazichopon tribe, which lived a nomadic life in the region close to Bulgaria, occupied the area between the Lower Danube and the southern arc of the Carpathian Mountains; the Kato Gyla/Chabouxingyla tribe, who were a four-day march from Tourkia, inhabited the area near the Prut and Siret

$38 \quad$ Sedov 1982, 132.

39 Györffy 1975, 283-292.

40 DAI, VIII $5^{-7}, 34-35$ (pp. 54, 56).

41 Györffy 1975, 29o. Notably, this way of nomadic life corresponds not only to Mongol customs, but also to the majority of Eurasian steppe peoples. Cf. Chapters 1 and 4.2 of the present book (economic considerations). 
Rivers; the Iabdiertim tribe, adjacent to the Slavic tribes under Rus', controlled the area between the Dniester and Boh; and finally, the Charaboï tribe lived on the right bank of the Dnieper River. Constantine's information on the location of the tribes of Eastern Patzinacia is somewhat less precise; however, based on the same premises, the Hungarian researcher places the nomads of the Kouartzitzour tribe on the left bank of the Dnieper River, the Syroukalpeï tribe on the Donets River, the Boulatzopon on the right bank of the Don, and the Borotalmat on the coasts of the Black Sea and the Sea of Azov, from the mouth of the Dnieper river to the mouth of the Don. ${ }^{42}$

Györffy's conclusions, although quite inspiring, are not without flaws. The researcher ignores certain archaeological data in his considerations, pointing to their questionable dating. ${ }^{43}$ However, the information provided by these sources cannot be ignored. Therefore, Györffy's interpretation needs to be revised. It is difficult to assume that the Giazichopon tribe already inhabited Wallachia in the first half of the 1oth century. It is equally unlikely that the Borotalmats would move along the northern shores of the Sea of Azov all year round. In this case, Györffy ignores the main premise underlying his own conclusions. However, many of his assumptions should be considered accurate. With some revisions, his placement of the left-bank Pechenegs, i.e., those inhabiting areas east of the Dnieper River, can be considered acceptable. The Kouartzitzour tribe could indeed have moved along the left bank of the Dnieper, the Syroukalpeï along the left bank of the Donets, and the Boulatzopon along the right bank of the Don. The Borotalmat tribe, on the other hand, could have

42 Györffy 1975, 290-291. Cf. Pálóczi-Horváth 1989, map no. 1 (pp. 8-9). For other attempts to locate tribes based on data provided by Constantine Porphyrogenitus: Csebe 1922, 209219; Pletneva 1958, 154; Pritsak 1975, 218-219; Romashov 1999, 25-32; Kniaz'kii 2003, 24-30; Parczewski 2007, 168 (fig. 3). Csebe's reasoning is based on the order in which the names of the various tribes are mentioned by Constantine Porphyrogenitus. The researcher focuses mainly on the tribes living on the right bank of the Dnieper River (cf. Tryjarski 1975a, 570-571; Kurat 1937, 52-55). Pletneva suggests a very general localization. Unlike Györffy, Pletneva does not place any of the tribes by the Danube. Pritsak allocates individual tribes mainly on the basis of data concerning the Pechenegs' neighbours, which makes his method highly debatable. Kniaz'kii is only concerned with the right-bank Pechenegs. He does not place any of the tribes on the Dniester, but locates as many as two tribes on the Danube (Giazichopon, Chabouxingyla). Although Michał Parczewski takes into account natural conditions, he completely ignores the realities of nomadic lifestyle. The last defect also applies to the other authors, which leads to acceptance of a fundamentally erroneous concept, according to which individual tribes among the nomadic community, such as the Pechenegs, would live only in the area of the steppe or forest steppe all year round, when in fact they had to move between them.

Györffy 1975, 287 . 
had their encampments on the right bank of the Donets or on smaller rivers flowing into the Sea of Azov. The location of the western tribes requires greater correction. The Charaboï most likely camped on the right bank of the lower Dnieper River. The location proposed by Györffy is supported by Constantine Porphyrogenitus' information that this tribe was a neighbour of the Rus' (most likely Kiev). In my opinion, the presumed location of the Iabdiertim should be moved to the right bank of the Boh. This location is also determined by archaeology. According to the information found in De administrando imperio, this tribe was supposedly located in close vicinity to groups which paid tribute to Rus', including the Uliches, who are usually thought to have inhabited an area by the Boh. The Gyla/Chabouxingyla tribe's nomadic habitat stretched along the right bank of the Dniester, which in its upper course approaches the arc of the Carpathians, which seems to explain mentions that this group of the Pechenegs was adjacent to Tourkia. The problem of the Giazichopon tribe's location raises the most doubts. Archaeological data and the reality of steppe life do not allow us to accept the Lower Danube as a location for their encampments. At the same time, however, this group's very close proximity to Bulgaria (half a day away) requires recognition of its presence in the area of the lower course of the river, close to its delta. Moreover, in the vicinity of Sulina, as mentioned above, the Pechenegs posed a threat to Rus' sailors. Both premises constitute hard evidence for the permanent presence of one of these Pecheneg groups in the area of the Prut-Dniester interfluve in the times of Constantine Porphyrogenitus.

At that time, the Giazichopon tribe most likely already had encampments there (mainly in Budjak, on the left bank of the Lower Dniester, and along the middle course of the Prut). This was not one of the most prominent Pecheneg groups, which suggests that it was also not very numerous. This made it relatively easy for members of the tribe to find a modus vivendi with local farming communities, as indicated by archaeological data proving the cohabitation of both populations. The location of the Giazichopon also gave them control over the Pechenegs' western sphere of influence.

To conclude our consideration of the territorial divisions of Patzinacia, it should be noted that the reconstruction presented here remains valid for the first three-quarters of the 1oth century. The collapse of the Khazar Khaganate, dated on the basis of data from The Tale of the Bygone Years to the year 965, which was accompanied by the expansion of the Uzes, brought about fundamental political changes on the Black Sea steppe. As a result of these changes, the image of Patzinacia in De administrando imperio in the last decades of the 1oth century would become less and less accurate, and by the beginning of the next century, would already have become history. 


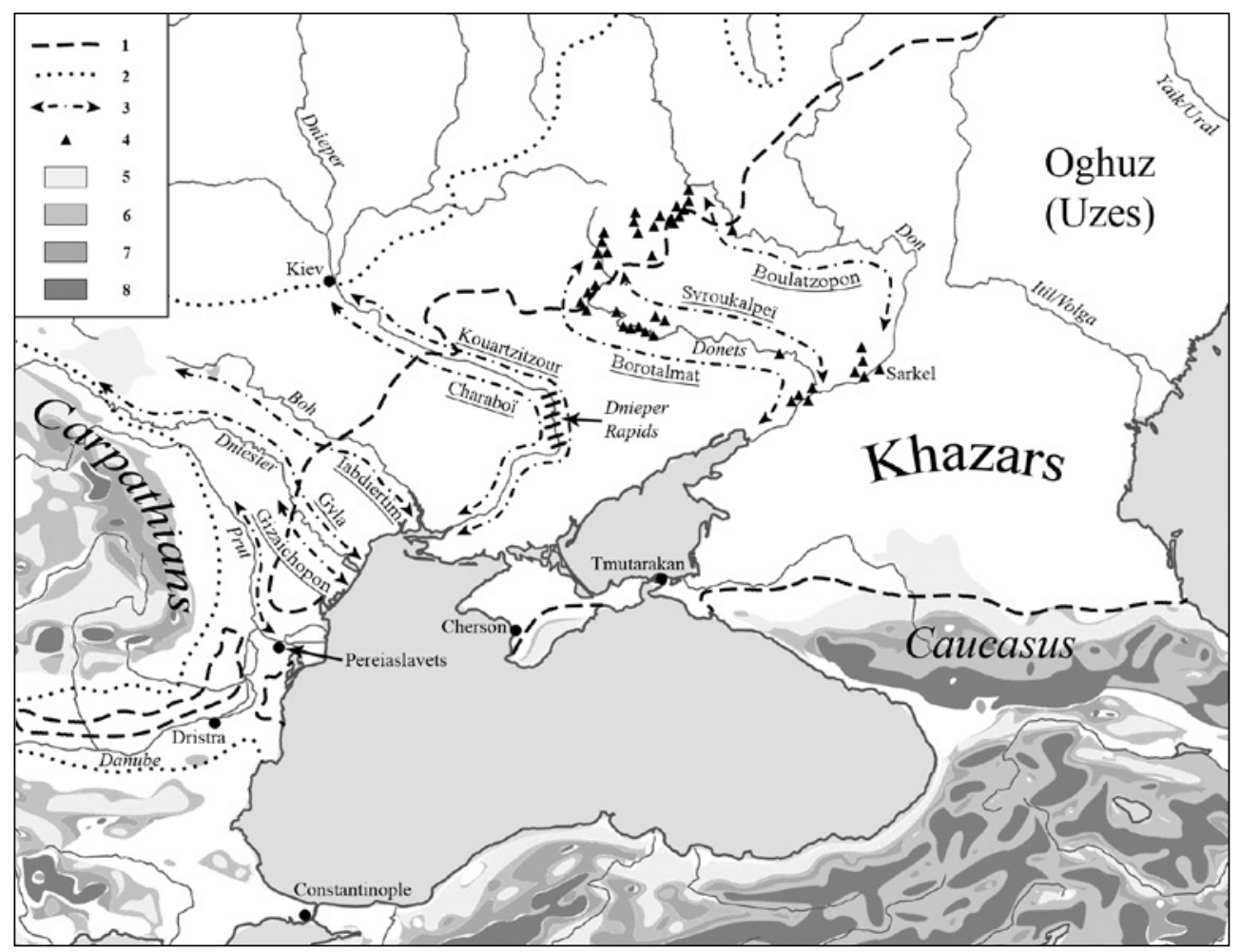

MAP 3

The Black Sea steppe in the Pecheneg Period, 1. Border of the steppe zone; 2. Border of the forest steppe zone; 3 . Seasonal migrations of the Pecheneg tribal groups; 4 . Saltovian hillforts and fortresses; 5.500-1000 $\mathrm{m}$ a.s.l.; 6. 1000-1500 $\mathrm{m}$ a.s.l.; 7. 500-2000 $\mathrm{m}$ a.s.l.; 8. Above $2000 \mathrm{~m}$ a.s.l.

\subsection{Political Relations between the Pechenegs and Their Neighbours}

Once the Pechenegs gained control of a large part of the Black Sea Steppe, the borders they shared with numerous powers of varying significance gave them the ability to play a pivotal role as a balancing force in regional affairs. Based on the factors discussed earlier in the chapter, it is clear that the Pechenegs faced significant hindrances to fully exploiting their favourable geopolitical position. The most important of these was the lack of a clearly established centre of power, which meant that the Pechenegs' behaviour in relations with the outside world sometimes involved impulsive behaviours, rather than deliberate political actions aimed at achieving some broader strategy. It is sometimes difficult to resist the impression that the role played by the Pechenegs in their external relations, although often significant, was mainly a negative one, i.e., a 
force posing a threat to neighbouring political powers. However, this perception seems to be an oversimplification.

The relationship best evidenced in the sources is that between the Pechenegs and the Byzantine Empire, a power that had a keen interest in developments on the Black Sea steppe. Initially, i.e., until the 97os, Crimea was the only place of contact between the nomads and the Byzantine Empire. The safety of Kherson and other Greek colonies on the southern shore of the peninsula depended on the quality of the relationship they maintained with the peoples who controlled their foreground. The city and thema of the same name were an important point from which Constantinople could observe the state of political relations north of the Empire's borders and provided a base for carrying out possible diplomatic action. ${ }^{44}$ This situation is reflected in the writings of Constantine Porphyrogenitus. ${ }^{45}$ However, the key importance of the Pechenegs became most evident in connection with Rus'-Byzantine relations. The Scandinavian founders of the Kievan state, before they were 'domesticated' and incorporated into the Byzantine Commonwealth, had long posed a potential threat to the Empire. This was particularly strongly demonstrated by the first Varangian invasion in $86 \circ .{ }^{46}$ It showed that Rus', using the waterway 'from the Varangians to the Greeks', could easily threatened Constantinople. This fact distinguished them from other barbarians, who were able to attack the capital of the Empire, but always reached its walls by land. Meanwhile, the Rus' were also capable of organizing a sea expedition. The safety of the capital city would decrease dramatically if the Kievan princes managed to establish settlements in Crimea. Evidence that they had made such attempts earlier can be found in one of the conditions of a treaty concluded in 944, in which Prince Igor pledged not to wage war on the peninsula. ${ }^{47}$ Success in such an endeavour would create a permanent threat not only to Constantinople, but also to the northern coast of Anatolia, which was the economic and demographic backbone of the Empire. ${ }^{48}$ This situation required that increasing priority be given to all political actions that could: 1) limit or completely halt Rus' invasions,

44 On the importance of Kherson for Byzantine politics in the Black Sea Steppe region: Wozniak 1979, 115-126; 1984, 301; Obolensky 1979, 123-133; 1993, 108-113; 1994, 7ff.; 1994a, 55-57; 2000, 171-177; Romanchuk 1993, 58-64; Shepard 1998a, 172-174; 2009, 429 et passim. DAI, I $25^{-28}$ (p. 48/49); VII (p. 54/55).

46 Vasiliev 1946; Ostrogorski 1967, 202; Levchenko 1956, 43-9o; Pashuto 1968, 57-88; Obolensky 1994a, 42-43; 2000, 182-184; Sacharov 1980, 48-82; Petrosian 1998, 41-43; Duczko 2004, 83-86.

47 PVL 1, AM 9453 (945), col. 50-51.

48 Ostrogorski 1967, 29o; Browning 1992, 106; Treadgold 1997, 371-380; Laiou, Morrisson 2007, 43-49. 
2) keep the Rurikids' state as far away as possible from the northern shores of the Black Sea, 3) be used to keep Rus' in check from the Black Sea steppe side if they were to settle in the Crimea.

Ever since the Bulgarians settled there, the Balkan Peninsula, i.e., the region located between the lower Danube and the Balkan mountains, had become crucial to the interests of the Byzantine Empire. ${ }^{49}$ The presence of a strong and independent state in the foreground of Constantinople (the Byzantine border fortress at Debeltos was eight days away from the capital of the Empire ${ }^{50}$ ) was a considerable challenge for the Empire, which was often forced to engage its forces in fights against enemies violating its borders to the east. The Christianization of the Bulgarians ( 865 or 866) during the reign of Boris-Michael and the subordination of the young church organization, despite its far-reaching autonomy, to the authorities in Constantinople (870), seemed to form the basis for long-term peaceful cooperation between the two states. ${ }^{51}$ The rule of Simeon I (893-927) put an end to these overly optimistic expectations. Throughout most of his reign, the Byzantine Empire was forced to fiercely defend its territorial integrity and political primacy in the Balkans. ${ }^{52}$ In such a situation, the inhabitants of the steppe could theoretically have been an important factor in counterbalancing the military power of Simeon's state. The Bulgarian ruler was probably also interested in, if not cooperating with the nomads, then at least in ensuring their neutrality in the event of a conflict with the Empire. The Pechenegs' taking control of the Black Sea steppe was therefore an event of great importance for both Constantinople and Preslav.

For Rus' and many East Slavic tribes the changes that took place on the Black Sea steppe initially had negative consequences. Their territories most likely became subject to armed incursions by their bellicose neighbours, ${ }^{53}$ with the intensity of these attack probably exceeded those experienced by the Byzantine Empire. In the case of Rus', the Pecheneg encampments were located on the border of the forest steppe, close to the capital city of Kiev. Moreover, the settlements established by war-like nomads on the lower course

49 Generally on Bulgarian-Byzantine relations: Browning 1975, 48-78; 1989, 23-32; Giuzelev 1996, 219-236.

$50 \quad$ Browning 1991, 615-616; 1997, 102.

$5^{1}$ Ostrogorski 1967, 203-204; Browning 1975, 56; Wasilewski 1988, 52-53; Bozhilov, Giuzelev 1999, 183-186; Leszka, Marinow 2015, 32-36, 43-52.

52 On Byzantine-Bulgarian relations and the political concepts of the Bulgarian ruler: Zlatarski 1927, 278-50o; Runciman 1930, 133-177; 1988, 81-101; Ostrogorski 1967, 221-222, 224-229; Browning 1975, 57-67; Bozhilov 1983; Fine 1983, 132-158; Bozhilov, Gjuzelev 1999, 239-270; Leszka 2011, 55-70; 2013; Marinow 2011, 155-19o; Leszka, Marinow 2015, 81-148.

53 This seems to be evidenced by the migrations of Slavic tribes, especially the Tiverians and the Uliches, discussed in the first part of this chapter. 
of the Dnieper River created a significant impediment to both trade and military expansion by Rus'. Considering that one of the Rurikids' main motives for conquering Kiev and the territory of the Polans was most certainly the desire to control the longest possible section of the trade route 'from the Varangians to the Greeks', the emergence of any obstacle limiting its use for trade was perceived by the Kievan rulers as an extremely undesirable circumstance. ${ }^{54}$

Little is known about the relationship between the Pechenegs and the Khazar Khaganate. There are few reasons to suppose that after the Pechenegs settled on the Black Sea steppe, relations between the recent enemies improved. It seems significant that Constantine Porphyrogenitus does not include the Pechenegs among the peoples likely to attack the Khazars. ${ }^{55}$ Meanwhile, another source mentions the formation of an anti-Khazar coalition established by Constantinople's diplomats during the reign of the Khazar ruler Benjamin. The coalition launched an attack, but was defeated with the help of the Alans. The Pechenegs were supposedly part of this group. ${ }^{56}$ It is difficult to date these events precisely. They probably took place in the late 9 th or early 1oth century. ${ }^{57}$ Regardless of how the relationships between these two peoples developed, the continued existence and ultimate fall of the Khazar state was of great importance for the history of the Pechenegs.

54 On the importance of trade for the Rus' state: Pashuto 1968, 62ff; Shepard 1974a, 27. Sakharov 1980, 84-134; Litavrin 1992, 48; 1999, 442; Franklin, Shepard 1996, 118-120, 133; Szymański 1973, 119-123. Cf. also chapter 4.2 of this study.

55 Among the enemies of the Khazar were said to be the Alans, the Black Bulgars, and the Uzes. DAI, X-XII (p. 62-65). Cf. Huxley 1984, 79-8o, 86-87; S. Runciman (1988, 115) assumed that the Pechenegs were not mentioned among the peoples capable of attacking the Khazars because an attack by them, according to the fears of Byzantine diplomats, could completely destroy the weakened Khaganate, which in turn, would have led to a political imbalance in the region. Such an explanation can hardly be considered satisfactory, since the enemies of the Khazars included the Uzes, who were as dangerous as the Pechenegs, if not more so. Recently, James Howard-Johnston recognized the Pechenegs as clients of the Khazars. Both in the period preceding and following their migration to the Black Sea steppe, they were likely to have been part of the Khazar system, as were the Kama Bulgars and the Magyars. However, the British researcher presents practically no evidence to support his thesis. Howard-Johnston 200o, 349-350, 355-356; 2007a, 183-186, 188-190, 191-192; 2007, 170, 172, 174.

$56 \quad$ Golb, Pritsak 1982, 112-115.

57 Cf. Golb, Pritsak 1982, 132-134 (Omelian Pritsak dates these events to 880-90o). Cf. Golden 1972, 77; Noonan 1992a, 115; Zuckerman 1995, 254 (just before 921-922). The last researcher, based on a very similarly sounding fragment of al-Gardizī, considers the possibility that the above-mentioned Khazar source recorded one of many clashes typical of the steppe. 


\subsection{The History of the Pechenegs before 945. At a Political Crossroads}

The relationships between the nomads and their neighbours outlined above involved geopolitical factors that potentially could, but didn't necessarily have to, lead to an alliance or war. The Black Sea steppe in that period was an area where the interests of neighbouring countries intersected, a fact which naturally increased the importance of the nomads who ruled over it. The nature of the Pechenegs' political organization and some elements of their culture may have discouraged political powers potentially interested in an alliance with them. Moreover, their arrival in the Black Sea region had been extremely violent. The Magyars who were banished from Etelköz were not the only one who experienced its dramatic consequences. The Pechenegs' raids, the main motive of which was most likely the desire to compensate for the material losses they had suffered during their clashes with the Khazars and Uzes, not only negatively impacted the East Slavic tribes, for they also affected the Kherson thema as well. Although no available source provides information on when and under what circumstances the nomads invaded the southern Crimean colonies of the Byzantine Empire, their wealth was probably a significant factor in motivating the nomads to attack. The claims of Constantine Porphyrogenitus contained in the first chapter of De administrando imperio were most likely based on concrete historical observations and cannot be treated as purely theoretical digressions. ${ }^{58}$ These expeditions may have brought significant material benefits to the Pechenegs, but they must have had a deeply negative impact on the quality of the relations between the nomads and the Byzantine Empire.

Apart from the attacks on Kherson, mutual distrust and hostility also resulted from a series of events that led to the arrival of the Pechenegs on the Black Sea steppe. We need to remember that their victory over the Magyars was achieved in alliance with the Bulgarian ruler Simeon I. ${ }^{59}$ With the help of the Pechenegs, he rid himself of troublesome neighbours who threatened his country from the north, which allowed him to defeat the Byzantine Empire at Boulgarofygon (896) and bring the war the two had been waging since 894 to a victorious end. ${ }^{60}$ The warring ruler's later contacts with the Pechenegs are unclear. It is not impossible that these relations were friendly for some time. According to Constantine's accounts, the Bulgarians, fearing nomad invasions,

$5^{8}$ DAI, I $25^{-28}$ (p. 48/49).

59 Cf. Chapter 3 of the present book.

6o Leszka 2011, 64; 2013, 76-95. 
tried to maintain a peace with them. ${ }^{61}$ This very general statement, however, does not give us sufficient grounds to assume the existence of a permanent alliance between Bulgaria and the Pechenegs. The events of the second decade of the 1oth century, when the nomads decided to enter into a short-term military alliance with the Byzantine Empire, also raise doubts. ${ }^{62}$ The thesis that the Pechenegs occupied the lands north of the Danube with the consent of Bulgaria as its foederati is nothing but pure speculation. ${ }^{63}$ The concept of close relations existing between these two peoples based on ethnic affinities is even less likely. Even if the Pechenegs spoke Turkic, a language close to Old Bulgarian, the formerly nomadic Bulgar elites had already undergone a farreaching process of Slavicization and acculturation in the early-1oth century. Thus, between the Bulgarians and the Pechenegs there were many more differences than similarities, especially after the Christianization of the former. Linguistic or cultural similarities, especially in that period, by no means determined the political choices of individual rulers or the communities they represented. In view of the reservations above, one should be very sceptical about the view shared especially by some Bulgarian historians about the existence of a strong and lasting Bulgarian-Pecheneg alliance. ${ }^{64}$

This does not change the fact, however, that cooperation, though probably quite short-lived, between the nomads and Simeon I during the 89os weakened the Byzantine Empire. Tensions in Bulgarian-Byzantine relations continued throughout the decade, with the conflict finally ending in 904. It cannot be ruled out that Simeon used the invasion of the Arab pirates led by Leo of Tripoli and Damian of Tarsus on Thessaloniki as an opportunity to impose advantageous changes in the border on the Byzantine Empire. Some researchers assume that the Bulgarian ruler incorporated part of the thema of Thessalonica into his country. Henceforth, the Bulgarian-Byzantine border would run just 22 kilometres north of this provincial capital. ${ }^{65}$

61 DAI V 10-13 (p. 52/53). However, Constantine's statement is unclear; it can be concluded that periods of peace were interrupted by fighting between the Bulgarians and the Pechenegs. The Emperor clearly states that the Bulgarians 'were sorely defeated by the

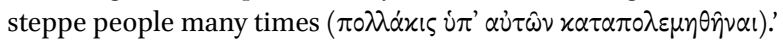

62 See below.

63 Tăpkova-Zaimova 1970, 71-72; Mladjov 1998, 95-96.

64 Bozhilov 1973, 52-53, 61;1983, 123-124 (the researcher suggests that the Bulgarian-Pecheneg alliance in the times of Simeon was most likely strengthened by marriages between representatives of the elites of both peoples); Dimitrov 2011, 205-210.

65 Zlatarski 1927, 321-342; Ostrogorski 1967, 222; Runciman 1930, 151-2; Wasilewski 1972, 225226; Browning 1975, 61; Bozhilov, Giuzelev 1999, 249; Stephenson 200o, 21; Leszka 2013, 100-115 (for a more careful stance). 
The events of 894-904 clearly showed that political relations between Constantinople and Preslav were far from harmonious, which was far from what one would have expected after the Christianization of Bulgaria. Moreover, the agreement reached in the early 1oth century offered no guarantee that a new phase in their conflicts and rivalry would not soon begin. The conquest of the Black Sea steppe by the Pechenegs must therefore have been seen by Byzantine diplomats as an extremely unfavourable occurrence, as it deprived them of an ally in the event of subsequent clashes with Simeon I.

In hopes of strengthening its position in its contacts with Bulgaria, as well as of limiting the political significance of the new neighbours of its southern Crimean colonies, the court in Constantinople decided to resort to a diplomatic ploy, described by Constantine Porphyrogenitus and carried out by an unknown cleric named Gabriel. The Byzantine emissary is said to have called on the Magyars to attack the Pechenegs and drive them from their new home on the Black Sea steppe. After recovering these lands, the Magyars would be in close proximity to the imperial court, which would enable faster and better contacts, allowing Constantinople to more easily delegate political tasks to the Magyars. ${ }^{66}$ The manner in which Byzantine diplomatic sources referred to their ally, or rather, judging from their tone, their political underling, is quite puzzling. It seems to prove that the Magyars were not perceived by them as an independent ethnos. ${ }^{67}$ However, establishing the approximate date of this mission is more crucial. The outstanding Hungarian Byzantinist Gyula Moravcsik assumed that it took place around 927, i.e., at the time of the peace treaty with Bulgaria. ${ }^{68}$ It would indeed seem that after Simeon's death, when, under the reign of Tsar Peter I, Bulgaria ceased its previous political expansion, Byzantium would be able to exercise greater influence over the political situation in the area north of the Black Sea. The sole aim of the cleric Gabriel's trip, therefore, according to Moravcsik's interpretation, would have been to curb the Pechenegs, because Bulgaria had already ceased to pose a threat. ${ }^{69}$ It seems, however, that the diplomatic move described by Constantine Porphyrogenitus would have been more justified earlier on. ${ }^{70}$ At that time, Byzantium would

\footnotetext{
66 DAI, VIII 23-33 (p. 56/7).

67 Cf. Moravcsik 1970, 54.

68 Moravcsik 1970, s. 54; DAI-Com., 16. Moravcisk's dating is also accepted by: Obolensky 2000, 155; Litavrin, Novosel'tsev 1989, 29 o (note 8); Shepard 1995, 111; 1999a, 270. Runciman (1988, 108 (note 3)) proposed an even later dating for the Gabriel's mission (948).

69 On Bulgaria during this period of Peter's rule: Runciman 1930, 177-202; Zlatarski 1927, 516-59o; Browning 1975, 67-72; Fine 1978, 88-95; 1983, 159-179; Bozhilov, Gjuzelev 1999, 271-307; Stephenson 2000, 23-25; Leszka, Marinow 2018. Cf. Bury 1906, 567. The author dates Gabriel's mission to the years 898-9o6.
} 
either have found itself in a fierce rivalry with Simeon or have faced the danger of the imminent resumption of one. The treaty of 904 thus may have been seen in Constantinople as merely a temporary solution. Moreover, the shifts in the border dictated by the treaty made it easier for the Bulgarians, in the event of the outbreak of a new armed conflict, to take effective offensive action.

The Empire must therefore have been particularly committed to seeking a strong ally against Simeon in the last phase of its conflict with Bulgaria, and even shortly afterwards, if we assume that the 904 treaty was regarded by Constantinople's diplomacy as merely a momentary cessation of hostilities. An additional factor that may have raised the Byzantine administration's awareness of the negative effects of the Magyars' absence on the Black Sea steppe was a Rus' invasion dated to $907 \cdot{ }^{71}$ The reconquest of the Black Sea steppe by the Magyars would have provided Constantinople with an ally capable of stopping the aggression of the Rus'.

Finally, the vigorous and very emotional reaction to the imperial order from the Magyars, who sent a threatening warning to a Byzantine diplomat, indicate they still clearly remembered the devastation the Pechenegs had inflicted on them. ${ }^{72}$ All of these issues seem to indicate that the cleric Gabriel's mission took place during the reign of Leo VI the Wise, in the late gth century or the first decade of the 1oth century.

This diplomatic failure and the outbreak of a new war with Bulgaria forced the court in Constantinople to attempt to establish some form of cooperation with the Pechenegs. This time the casus belli according to Simeon I was the refusal of Emperor Alexander I to pay the tribute guaranteed by earlier agreements. ${ }^{73}$ The situation in Byzantium was further complicated by the imminent death of the emperor (June 913) and the fact that the regency council, initially led by Patriarch Nicholas Mystikos, assumed power in the name of the young Constantine vir. Mystikos supported a policy of reconciliation with the Bulgarian monarch, who soon arrived to Constantinople with his armies (August 913). An agreement was concluded that gave Simeon the title of basileus of the Bulgarians and called for the marriage of his daughter to the

71 PVL 1, AM 6415 (907), col. 29-32. Cf. Jenkins 1949, 403-406; Sakharov 1980, 84-104; Obolensky 2000, 184-5; Franklin, Shepard 1996, 103-105.

72 DAI, VIII 29-33 (p. 56).

73 According to most sources, Simeon only demanded confirmation of the conditions of the already existing peace, which Alexander I recklessly rejected. The only author who mentions tribute being paid to the Bulgarians is John Skylitzes. Th.Cont., 38 o; LeoGramm., 287; Sym.Magist., 134.8 (p. 296-297); Io.Scyl., 195; Wortley 2010, p. 19o. Cf. Ostrogorski 1967, 225; Runciman 1988, 46; Leszka 2013, 118-123; Leszka, Marinow 2015, 100-107. 
young Constantine. ${ }^{74}$ The terms of the agreement, especially the planned marriage aroused strong opposition from some Byzantine elites, who gathered around Empress Zoe Karbonopsina, widow of Leo VI and the young emperor's mother. Eventually, the arrangements made by Nicholas Mystikos were disavowed and his role in the Regency Council was limited. This placed the Empire once again on a path to military confrontation with Bulgaria, especially given that Simeon I had taken military action against the Empire upon hearing that the treaty had been broken. Zoe and her circle are said to have responded with military operations by a coalition composed of Byzantium and its allies, including the Pechenegs. ${ }^{75}$ The person responsible for the alliance with the nomads was John Bogas, the strategos of the Kherson thema. He pledged, in exchange for the title of Patrician, to persuade the Pechenegs to take military action against Simeon I. With the required customary gifts in hand, the Kherson strategos travelled to the various Pecheneg tribes and reached an arrangement with them. ${ }^{76}$ The brief mentions by Byzantine chroniclers seem to indicate that this mission was not a difficult one. In particular, the regular pattern in the delivery of gifts suggests that Bogas' actions were considered part of a diplomatic routine. However, events most likely took a completely different turn. Correspondence between Nicholas Mystikos and Simeon I, provides us with cause to take a closer look at the circumstances in which the agreement with the Pechenegs was concluded. A letter written

74 The first provision of the agreement is universally accepted in modern scholarship, while the second one raises doubts. For the traditional position (the 913 agreement included both provisions): Ostrogorski 1967, 226; Browning 1975, 62; Runciman 1930, 156-157; 1988, 51; Treadgold 1997, 473; Stephenson 200o, 22; Cheynet 2006, 28. Criticism: Leszka 2013, 142-146; Leszka, Marinow 2015, 108-111.

75 Zlatarski 1927, 374-380; Ostrogorski 1967, 226; Runciman 1930, 158-159; Bozhilov 1983, 120-125; Treadgold 1997, 473-475. This traditional perception of the events is contrasted with another one, according to which Simeon did not act as the aggressor. The provisions of the 913 agreement fully satisfied him and were in no way violated by the Byzantine side. The latter, however, decided to break the peace treaty by undertaking military action in 917. Cf. Shepard 2011, 34-45; Leszka 2013, 160-176; Leszka, Marinow 2015, 118-121. However, such a version of events raises doubts. First of all, it poorly explains the reasons why Nicholas Mystikos lost his influence to Zoe Karbonopsina. It seems that the reason the Patriarch was banished to the political periphery was his concessions, which must have gone further than merely accepting the title of "Basileus of the Bulgarians" granted to Simeon. Secondly, the reasons that led the Byzantine court to take aggressive action against the Bulgarian monarch are unclear. If the latter had not undertaken any armed actions, it seems unreasonable for Constantinople to have dispatched a complicated and probably very expensive war expedition to the Balkans.

76 Th.Cont., 387; Georg.Mon., 879; LeoGramm., 293; Sym.Magist., 135.14 (pp. 302-303); Io.Scyl., 201-202; Wortley 2010, 196. 
by Nicholas to Simeon I shortly after the Battle of Anchialos, which had been catastrophic for the Empire (20 August 917) clearly shows that in the period preceding the clash, the nomads had been the target of diplomatic efforts by the Bulgarian ruler. The strategos of the Kherson thema reported that the Pechenegs informed him many times about proposals for an alliance from Bulgaria. Simeon's subjects were ready to secure such an alliance through marriages, which seems to indicate how important such a union was to them. ${ }^{77}$ Ultimately, however, the Byzantine side gained the upper hand.

The Patriarch's letter contains additional facts worth noting here. First, the head of the Byzantine Church shows a clear reluctance towards the arrangement between the Pechenegs and its executor. ${ }^{78}$ The tone of Nicholas Mystikos' description of Bogas' actions suggests he felt a need to justify them. According to his account, Constantinople agreed to negotiate with the Pechenegs only because it had learned about the earlier actions of Bulgarian diplomats. The diplomatic efforts of the Byzantine court were therefore defensive in nature. ${ }^{79}$ However, this does not change the fact that the Patriarch considered the agreement with the nomads to be wrong, exacerbating a great injustice, that is, the Bulgarian-Byzantine conflict itself. ${ }^{80}$ This observation seems to explain to some extent the attitudes of some Byzantine elites of that period. Perhaps it constitutes an additional explanation as to why the agreement with the Pechenegs was not consumed at the decisive moment. ${ }^{81}$ Nicholas Mystikos also mentions the arrival of some 16 Pechenegs in Constantinople, who also reported on the actions of Simeon's diplomats. ${ }^{82}$ This mention is particularly interesting. A problem worth considering here is who organized the visit of the nomads to the capital of the Empire. In other words, was it initiated by the Pecheneg elites or by the strategos of the Kherson thema. In the light of available source data, both options seem equally possible. However, it should be noted that the nomads benefited greatly from the diplomatic rivalry between the Byzantine Empire and Bulgaria. It is therefore not unlikely that it was their decision to inform the imperial court of the intentions of the Bulgarian ruler,

77 Nic.Mist., Ep. 9, p. 58 (v. 98-112); Cf. Malamut 1995, 107-108.

78 Nic.Mist., Ep. 9, p. 6o (v. 148). The Patriarch calls Bogas and the Pecheneg emissaries wretches ( $\dot{\alpha} \theta \lambda i o \iota \dot{\alpha} v \theta \rho \dot{\omega} \pi \circ \mathrm{l})$.

79 Nic.Myst., Ep. 9, pp. 6o, 62 (v. 142-152).

8 o Nic.Myst., Ep. 9, p. 62 (v. 163-172). Cf. Nic.Myst., Ep. 183, p. 514 (v. 22-26).

81 Cf. interesting observations by Mirosław J. Leszka concerning the views of Nicholas Mystikos and Theodore Dafnopates (a.k.a. Romanos Lekapenos) on the spilling of Christian blood and the use of pagans in the fight against Christians. The latter is supposed to have been a manifestation of the greatest evil. Turning to pagans for help is allowed only in extraordinary cases (a threat to one's independence). Leszka 2006, 14; 2008, 36-38.

$82 \quad$ Nic.Myst., Ep. 9, p. $5^{8}$ (v. 105-107). 
with the aim of initiating a kind of political bidding war. ${ }^{83}$ The Kherson strategos most likely merely acted as an intermediary.

Bogas' mission, or rather his negotiations, should be dated between summer or early autumn of 914 and mid-917. It was part of much broader preparations for a military offensive against the Bulgarians. The Magyars and Serbs also became objects of Constantinople's diplomatic efforts. ${ }^{84}$ Zoe Karbonopsina also decided to enter into a peace agreement with the Arabs, as she sought to move more troops from the eastern border. These forces, supported by the armies of the West, were supposed to attack Simeon. ${ }^{85}$ After long preparations during the summer of 917, Byzantine troops led by Leo Phokas finally entered into enemy territory and moved north along the Black Sea coast. The second part of the plan was to move the Pechenegs across the Danube. This task was assigned to Romanos Lekapenos, the great droungarios of the fleet. The nomads were to link up with the main Byzantine forces and join the fight against the Bulgarians. However, such a coordinated action never took place. According to Byzantine sources, the Pechenegs could not complete this task due to misunderstandings between Lekapenos and John Bogas. Due to this conflict, the nomads returned to their homes without engaging in combat. ${ }^{86}$ Blame for this course of events fell on the droungarios of the fleet, who refused to carry out orders. The reason for his behaviour may have been his distrust of the Empire's newly recruited ally. ${ }^{87}$ However, political rivalry was an equally important motivation. It cannot be ruled out that Lekapenos had initiated a risky gambit aimed at discrediting the regent's current policy. He may have assumed that the failure of the 917 campaign would undermine the power of Zoe and her political clients. 88

The reason for the Pechenegs' withdraw, however, was not likely to have been some other sub-group of the nomads allying itself with Simeon. Some researchers have suggested that the nomads, bound by an alliance with Byzantium, retreated in order to avoid a fratricidal war once they learned that kindred nomads were fighting on the Bulgarian side. Pechenegs who had

\footnotetext{
83 Cf. Malamut 1995, 108.

84 DAI, XXXII 86-91 (p. 156); Cf. Bozhilov 1983, 122-123; Leszka 2013, 169; Leszka, Marinow 2015, 121-122.

85 Th.Cont., 388; Georg.Mon., 88o-881; Sym.Magist., 135.18 (p. 304); LeoGramm., 294; Io.Scyl., 202-203; Wortley 2010, 197 .

86 Th.Cont., 389-39o; Georg.Mon., 882; Sym.Magist., 135.21 (p. 305); LeoGramm., 295-296; Io.Scyl., 204; Wortley 2010, 198-199.

87 Cf. above, Nicholas Mystikos's clear objections to cooperation with the Pechenegs.

88 The struggle between political factions as a reason for the failure of the Byzantine campaign of 917 clearly appears in the narrative of Leo the Deacon, who was writing more than half a century later. LeoDiac., VII 7 (pp. 122-124); Talbot, Sullivan 2005, 170-172.
} 
chosen to ally themselves with Simeon I are said to have stood by him and supported his forces at Anchialos. ${ }^{89}$ This interpretation is not very convincing. It seems unlikely that Byzantine sources were unaware of the fact that during the 917 campaign a significant number of Pechenegs fought on the side of the Bulgarian monarch. While such a lack of knowledge might have been true for the chroniclers, the same cannot be said of the well-informed Nicholas Mystikos, who lived at the time of these events. If he had considered it necessary to explain the reasons and circumstances behind the formation of a Pecheneg-Byzantine alliance, it is difficult to imagine that he would not have pointed to and criticized Simeon's actions. The presence of the Pechenegs in his ranks would have, after all, bolstered the concerns of Zoe and her followers, which were given as the official justification for the alliance with the nomads.

The source data referred to by researchers who claim that a group of nomads entered into an alliance with Bulgaria does not provide sufficient grounds to support their thesis. The rebellion $(\dot{\varepsilon} \pi \alpha \nu \alpha \dot{\sigma} \sigma \alpha \sigma \varsigma)^{90}$ mentioned in The Martyrdom and Miracles of St. George of Cappadocia, which western barbarians were said to have launched against the Byzantine Empire, among

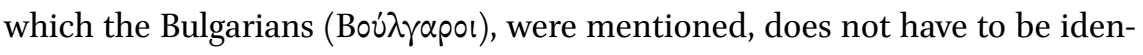
tified with the events that culminated in the Battle of Anchialos. The ethnonyms of the barbarian coalition partners are particularly difficult to interpret. Apart from the Bulgarians, the author of the biography also mentions the

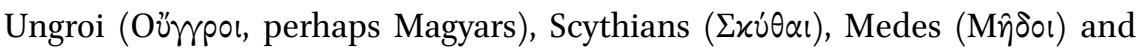
Turks (Tov̂prot). These archaic ethnonyms leave much room for interpretation. Only the a priori assumption that the Pechenegs were among them allows us to link them to the Scythians mentioned by the text's author. However, such an assumption cannot be considered methodologically valid. The supporters of the Bulgarian-Pecheneg alliance also refer to al- Mas'ūdì's account of the invasion of the Walandar fortress by four barbarian peoples. The claims of the Arab historian will be addressed below. Here it is worth stating merely that considering the description of the Battle of Walandar and the siege and conquest of that fortress to be the same as the events described as part of the Battle of Anchialos in August 917 faces two obstacles, which in my opinion are impossible to overcome. First, none of the four peoples mentioned by Mas'ūii can be identified as the Bulgarians. The only researcher who had made an attempt to

89 Bozhilov 1973, 46-52; 1983, 124. Ivan Bozhilov's interpretation has gained some recognition: Dimitrov 2011, 198-205; Marinow 2007, 384; Leszka 2013, 171-173. However, the positions of both Polish researchers are much more cautious. 
do so was Carlile A. Macartney. ${ }^{91}$ His identification, however, has been rejected by scholars. The second is related to chronology. Mas'ūdī claims that the events he described occurred in the year 932 or later. The participation of the Magyars means the year was 934, when their invasion (also known from Byzantine sources) reached the walls of Constantinople (this fact was also noted by the Arab historian). An additional fact that confirms the above dating of the Battle of Walandar is an indication that the Emperor of Rome (ar-Rūm) was then someone named 'Armanos.' He should be identified as Romanos I Lekapenos, whose reign, as we know, began only in $920 .{ }^{92}$

Therefore, during the 917 campaign, the Pechenegs ultimately did not support any sides in the conflict, which to a large extent determined the Byzantine Empire's defeat. On 20 August, Leo Phokas' army was completely destroyed in the Battle of Anchialos. After this defeat, another, at Katasyrtai, near Constantinople, soon followed. The Empire was no longer able to defend itself, which was eagerly exploited by Simeon. A year later he invaded northern Greece and reached the Gulf of Corinth during a looting expedition. ${ }^{93}$

Romanos Lekapenos' risky political manoeuvring out him in great danger. At one point, he even faced the risk of having his eyes put out. It was only through the intervention of Magister Stephen and Patrician Constantine Gongyles, two people with significant influence over Zoe, that he managed to avoid such a punishment. ${ }^{94}$ Meanwhile, the days of the regent's power were numbered. Her downfall finally came about in the spring of 919. Romanos Lekapenos became the new regent with the title of basileopator, which he soon changed to kaisar (Caesar), and on 17 December 920, his son-in-law Constantine viI elevated him to the position of co-emperor. ${ }^{95}$

The first Pecheneg-Byzantine agreement recorded in sources proved to be short-lived, and its provisions were never implemented. Romanos I Lekapenos, who was largely responsible for breaking the alliance of 917 , did not assign the Pechenegs a significant place in the system of Byzantine alliances. Ideas on how to make use of the steppe people during the prolonged conflict with Simeon

\footnotetext{
91 Macartney 1930, 162. Cf. below.

92 Cf. below.

93 Zlatarski 1927, 385-392; Runciman 1930, 16o-162; 1988, 161-163; Ostrogorski 1967, 226; Treadgold 1997, 475; Leszka 2013, 177-180, 182-185, 188-19o. The last scholar is seemingly rightly inclined towards a more nuanced assessment of the Battle of Katasyrtai. It was not a failure for the Byzantine armies; they suffered serious losses (the death of one of the commanders), but they stopped the advance of the Bulgarians.

94 Th.Cont., 39o; Georg.Mon., 882; LeoGramm., 296; Sym.Magist., 135.22 (pp. 305-306); Io.Scyl., 204-205; Wortley 2010, 199. Cf. Runciman 1988, 56.

95 Io.Scyl., 209, 212; Wortley 2010, 202, 205. Cf. Ostrogorski 1967, 228; Runciman 1988, 58-62.
} 
were most likely put forth by those around the emperor. This is evidenced by information contained in another letter from Nicholas Mystikos, dated 922, to the ruler of Bulgaria. The Patriarch calls for a cessation of fighting, threatening otherwise to form an anti-Bulgarian coalition under the patronage of Constantinople. This coalition was to comprise various 'Scythian' peoples, i.e., the Pechenegs, Rus', Magyars and Alans. ${ }^{96}$ The tone of the letter, which sounded like a reprimand and a call for improvement, and, as the author makes clear, to work in concert with the court in Constantinople, leads us to the conclusion that the idea of a vast alliance against Bulgaria was more of a diplomatic bluff than a real threat. ${ }^{97}$ Moreover, it would seem unwise to have informed Simeon about the real plans of the Byzantine court, as it could have led to diplomatic moves on his part to thwart them. What is more, the Pechenegs are portrayed here as one of several possible partners of the Empire, and not as the main one. Thus, it seems that the Pechenegs did not play a major role in the political plans of Constantinople, not only until the death of Simeon, which ended the Bulgarian-Byzantine conflict, but almost to the end of Romanos I Lekapenos' reign. There is also nothing to indicate the existence of any particularly close relations between Preslav and the nomads. On the contrary, it would seem that the strong involvement of Simeon's Bulgaria in the Balkans could even have resulted in losing its political influence in the Danube areas to the Pechenegs. ${ }^{98}$

Events connected with the mission of John Bogas can be considered evidence of a change in the attitude of the Pechenegs towards the population of Kherson. It is difficult to determine whether their trade contacts, well documented in De administrando imperio in the mid-1oth century, ${ }^{99}$ led to an attempt at political cooperation. However, this seems quite likely. Plans for a political alliance were made in response to Simeon's previously described diplomatic activity, which indicates that no such relationship had existed earlier between the nomads and Byzantium. This attempt at political cooperation could have been facilitated by the trade ties that existed between the two sides. They were most likely also the source of the knowledge possessed by the Kherson strategos about the efforts of Bulgarian diplomats. The failure of the Byzantine-Pecheneg alliance, however, did not necessarily end the economic cooperation between the inhabitants of the thema with their steppe neighbours.

\footnotetext{
96 Nic.Myst., Ep. 23, p. $15^{8}$ (v. 15-21), 16o (v. 66-72).

97 Bozhilov 1983, 139; Dimitrov 2011, 206; Shepard 1998, 29.

98 Cf. Runciman 1930, 15o; Browning 1975, 68; Treadgold 1997, 479. Cf. also the considerations in the first part of this chapter.

99 Cf. Chapter 4.2 of the present book.
} 
The relationship between the Slavic peoples and the Pechenegs had a difficult start as well. There is a number of reasons to suppose that Pecheneg looting raids affected their northern neighbours particularly severely. In delineating the borders of Patzinacia, we could notice that almost all the Eastern Slavic tribes who were adjacent to the steppe were forced to move their residences to the forest zone, which provided greater protection against attacks by the nomads. The range of the Pechenegs' armed penetrations sometimes extended past the northern border of forest steppe, which proves that even there the Slavs did not enjoy a complete state of peace. The situation was particularly unfavourable for the Uliches and Tiverians, who, due to their close proximity to other Slavic tribes, could not leave the forest-steppe zone completely, and thus faced a permanent threat from their bellicose neighbours. It seems, however, that over time, the Slavs were able to find a modus vivendi with the nomads. A flexible tribute payment policy most likely helped them to establish a more peaceful relationship. A sign of these relations can be found in Chapter Two of De administrando imperio, according to which the inhabitants of Rus' bought sheep, horses and cattle from the Pechenegs. ${ }^{100}$ A statement by Witold Hensel was quoted above; ${ }^{101}$ according to him the trade in goods described by Constantine Porphyrogenitus was mostly beneficial for the nomads, which makes it a form of tribute. ${ }^{102}$ This was most likely one of the ways the Pechenegs' attacks were limited, which could have brought at least a partial normalization to their relations. ${ }^{103}$

Another factor limiting the Pechenegs' aggression was the Rus' political organism, although it was still in a nascent state. The Varangians constituted a military counterbalance to the warrior steppe people. The Rus' princes only began to settle permanently in the area of the middle Dnieper at the end of the first third of the 1oth century; however, this does not change the fact that they most likely had been interested in this area since well before this time. The Rus' gradually filled the place once occupied by the Khazar Khaganate, assuming control of the eastern Slavic tribes. The Ledzanians, Uliches, and Derevlians were all described as tributaries of the Rus' state in De administrando imperio. This seems to indicate that the Rus' domination could have provided some form of protection against potential aggression by the Pechenegs. ${ }^{104}$

\footnotetext{
100 DAI, II 5-8 (pp. 48-51).

101 Cf. Chapter 4 (section 2) of the present book.

102 Hensel 1987, 113, 688.

103 Cf. Łowmiański 1973, 126-127.

104 DAI, XXXVII 43-45 (p. 168/169). Cf. Franklin, Shepard 1996, 97-98, 110, 121-13o; Duczko 2004, 217-225.
} 
The expansion of control over the eastern Slavic tribes and the trade routes running toward the Byzantine Empire therefore had to lead to a rivalry between the Rus' and the Pechenegs. Evidence of the existence of such a rivalry can be found in Rus' chronicles. Judging from these records, this conflict was initially not particularly fierce, but then, they note, around the year 915:

The Pechenegs entered the land of Rus' for the first time, but when they made peace with Igor', they went their way to the Danube. ${ }^{105}$

This is followed by a description of a military expedition organized against Simeon which ended in failure due to mistakes made by the Byzantine commanders. The combination of these two events seems to prove that the aforementioned expedition by the nomads was a preventive measure, aimed at securing the Pechenegs' home base from a counterattack by Igor while their forces were away fighting on Bulgarian territory. The latter fact would seem to indicate that the date of the Pecheneg expedition against the Rus' should be changed to 917. Their actions provide evidence that, contrary to the chroniclers' accounts, the nomads had been at war with the Rus' Prince for some time. It is not clear at what date these hostilities began. It is likely that the Pechenegs attacked Rus' around 914, when a part of the Rus' forces were on a looting expedition along the southern coast of the Caspian Sea. ${ }^{106}$ The short period of time separating the two events would justify the nomads' fears that the Rus' ruler would use their temporary vulnerability to organize a retaliatory expedition against them for the harm they had recently inflicted upon his people.

The next clashes probably took place around 920. This time the mention in the chronicles is even more laconic:

Romanus was set up as Emperor in Greece. Igor' waged war against the Pechenegs. ${ }^{107}$

105 PVL 1, AM 6423 (915), col. 42-43; Cross, Scherbowitz-Wetzor 1953, 71.

106 The date of this expedition has been a subject of controversy. Mas'ūdī states that it took place after 300 Hijra (912-913 of the Christian era); he forgot the exact date. The Rus' seized ample loot, half of which, according to an earlier agreement, was given to the Khazar ruler. On their way back, however, after passing through the Volga estuary, they were attacked by Muslim mercenaries of the khagan, and then by the Burtas and Bulgars of the Volga. Most of the Varangians were murdered. al-Mas'ūdī, Les Prairies, II, 18-24; Pellat 1962, 165-167; Dunlop 1954, 209-212. Cf. Łowmiański 1973, 197; PVL 2, 282; Novosel'tsev 199o, 212-213; Zuckerman 1995, 256.

107 PVL 1, AM 6428 (920), col. 43; Cross, Scherbowitz-Wetzor 1953, 71. 
It is difficult to deduce from this passage - assuming the information contained in it is reliable - who was acting here as the aggressor. It was possibly the Rus' prince. ${ }^{108}$ If this was the case, it is still difficult to say what motivated Igor to take military action against the steppe people. Accepting the standard hypothesis that this was a punitive expedition presupposes that it was preceded by some kind of Pecheneg provocation. It is also quite probable that it did not take place on Rus' territory, but somewhere along the part of the Dnieper trade route controlled by the nomads. The fighting mentioned above could also have been a consequence of Rus' activity on this waterway that was either seen as undesirable by the Pechenegs or which had not previously been negotiated with them.

For nearly half a century, i.e., until 968 , the sources remain silent about the armed actions taken by the nomads against the Rus'. It would be extremely risky, however, to conclude that relations between the Pechenegs and Kiev were perfectly peaceful during that time. Confrontations provoked by both sides most likely took place. Their frequency and intensity, however, was clearly not high. The proximity of the territories of the Rus' and Pechenegs would not have been so close (only a day's journey in the times of Constantine VII) if a fierce rivalry had continued to exist between the two political powers. However, the establishment of settlements along the middle course of the Dnieper could have led to a violation of the borders of the spring and summer encampments of the Pechenegs located in the forest-steppe zone. Such a situation would clearly have provoked conflicts. This was also the case in terms of Pecheneg looting raids on lands inhabited by tributaries of Kiev or merchants active on the Dnieper route. Events of this kind most likely also took place and weighed on the quality of the relations between the steppe-dwellers and Rus'. Nevertheless, their importance was not sufficient to leave a trace in written sources. Moreover, short-term armed conflicts did not necessarily exclude the possibility of temporary cooperation. It is hard to imagine that the Rurikids could lead a four-month expedition against Byzantium in 941 without ensuring at least the benevolent neutrality of the nomads beforehand. Three years later, Igor even managed to persuade the Pechenegs to engage in military cooperation against Constantinople. ${ }^{109}$

Before this happened, however, the Pechenegs were said to have joined forces with another political partner in order to stand up militarily against the Empire. These events, dated to 934, were described by al-Mas'ūdī. In Chapter 17 of Meadows of Gold he writes:

108 A similar interpretation is adopted by S.A. Pletneva $(1958,215)$.

109 Cf. below. 
We will therefore return to the account of the nations which live in the neighbourhood of Bab el-Abwab, the wall, the Caucasus, the country of the Khazar, and the Alans. On the frontiers of the Khazar towards the west, live four Turkish nations, which derive their origin from the same forefather. Some of them are settled, whilst others are nomads. They are all brave and can resist any nation. ${ }^{110}$ Each of them has its own king, whose dominions have an extent of several days, and they are contiguous to each other. Some of them are on the Pontus. They extend their predatory excursions as far as Rome which is in the direction towards Spain. ${ }^{111}$ They are victorious over all the nations who live there. Between the king of the Khazar and the lord of Alan a friendship exists. ${ }^{112}$ They are immediate neighbours of the former. The first of these nations has the name Bajna. The second is called Bajghird the next following nation is called Bajnāk, and is the bravest of the four. The fourth is called Nūkardah. Their kings have sovereign power, they had wars with the Byzantines after the year 320 A.H. or in that year. ${ }^{113}$ The Byzantines have, on the frontiers towards these four nations, a large Greek city which is called Walandar which has a great population (garrison), and is protected by the sea on one side, and by mountains on the other. The inhabitants (garrison) of this town defended the country against the invasions of the before mentioned four Turkish nations, and they were unable to penetrate into the country of the Byzantines, being precluded by mountains, the sea, and this town. These four nations have been at war with each other, on account of a dispute respecting a Muslim merchant of Ardabill, who, although he enjoyed the protection of hospitality of one of these nations, was injured by another. This gave rise to disunion. The Byzantines of Walandar took advantage of it, invaded their country whilst they were disunited; they took many of their children prisoners, and plundered their property. When they heard of this, as they were occupied in their war, they united under one commander, proclaimed a mutual amnesty, remitting blood

110 Cf. de Meynard and de Courteille (al-Mas'ūdī, Les Prairies, II, 58): Elles sont puissantes et belliqueuses; Douglas Morton Dunlop (1954, 212): They [...] are difficult of approach and very courageous.

111 Cf. de Meynard and de Courteille (al-Mas'ūdī, Les Prairies, II, 58): Elles poussent leur excursions jusque sur les terres de Roum et les provinces voisines de l'Espagne; Dunlop $(1954,212)$ : Their raids extend to the lands of Rome and almost as far as Spain.

112 Cf. de Meynard and de Courteille (al-Mas'ū ūī, Les Prairies, II, 58-59): [...] ells vivent en paix avec le roi des Khazars, [...], et avec le roi des Alans; Dunlop (1954, 212): Between them and the king of the Khazars is a truce, and so with the ruler of the Alans.

113 Cf. de Meynard and de Courteille (al-Mas'ūdī, Les Prairies, II, 59; Pellat 1962, 178): durant l'année 320 , ou peu aprés. 
revenge; and the whole nation, about sixty thousand horse strong, ${ }^{114}$ at once repaired to the town of Walandar, and this without being called out, and without collecting the men. If they had called out their men, they would have mustered about one hundred thousand horsemen. When Romanus who is the present emperor of the Byzantines, that is to say, in $332 \mathrm{AH}$, had received intelligence, he sent against them twelve thousand (Arabic) horsemen who had embraced the Christian religion, with spears in the Arabic costume and fifty thousand Byzantines. They came in eight days to the town of Walandar encamped beyond the town, and took (partly) their quarters in the houses of the inhabitants. The Turks had already killed a vast number of the population of Walandar, but they defended themselves with their walls till this reinforcement reached them. When the four kings had observed that their enemies had received the aid of those (Arabs) who had turned Christians, and of the Byzantines, they sent unto their own country, which lies towards the country of the Khazar, Alans, Bab el-Abwab, and others, and collected the Muslim population who did not enlist except in wars against unbelievers. When the two armies had drawn up in battle array, the Christian Arabs advanced in front of the ranks of the Byzantines; and, on the side of the Turks, the merchants who were in their army proceeded from the ranks, and invited them to the Mohammedan religion, promising to bring them into the Muslim territory, if they would take quarter from the Turks. They refused to accept these terms, and they fought a general battle, in which the Christian Arabs and Byzantines were superior to the Turks; for their number was many times greater than that of their enemies. They remained that night at their posts. The four Turkish kings held a council, in which the king of the Bajnāk said, "Give me the command tomorrow morning." They agreed to give it to him; $[\ldots] . .^{115}$

The 'Turks' prevailed over the Byzantine army. The bodies of 6o,ooo dead Greek soldiers said to have remained on the battlefield were stacked up and used to scale the walls of Walandar. The conquered city was plundered and a large part of its inhabitants were murdered or taken into captivity. Mas'ū ūī adds:

114 An unauthorized revision by a translator. In the original 6o,ooo warriors. Cf. al-Mas'ū ūī, Les Prairies, II, 6o; Marquart 1903, 62; Dunlop 1954, 213.

115 The English translation of A. Sprenger $(1841,446-450)$ has been slightly modified. Other modern translation of this passage: al-Mas'ū $\mathbf{d} \overline{1}$, Les Prairies, II, 58-62; Pellat 1962, 177-179; Marquart 1903, 61-62; Dunlop 1954, 212-214; Konovalova 1999, 5-6; Konovalova, Perkhavko 200o, 147-148. 
After three days, the Turks proceeded towards Constantinople. They passed a number of cultivated districts, meadows, and estates, spreading slaughter and taking prisoners, till they came to the walls of Constantinople. There they staid for about forty days, and sold the captive women and children for linen, cloths of brocade, and silk. They put the men to the sword, none received quarter; sometimes they did not spare even women and children. They made predatory excursions all over these countries, and as far as the country of the Sclavonians and Rome. At present their invasion extends even to the frontiers of Spain, ${ }^{116}$ France, and Galicia. The predatory incursions of the above-mentioned Turkish nations continue to this day to infest Constantinople, and the above-mentioned kingdoms. ${ }^{117}$

Both passages cited above have long been of interest to researchers. There is a consensus among them that Mas'ūdî's account describes, albeit in a distorted form, events that actually took place. In a manner typical of Muslim writers, the author draws attention to the achievements of his fellow believers, sometimes resorting to obvious exaggerations. The scale of the battle of Walandar in Mas'ūdî's narrative must also arouse scepticism in the critical reader. It is hard to imagine that a battle in which, if we believe the Arab historian, well over 100,00o warriors fought, would have gone unnoticed by Byzantine historiography. Finally, the chronology of the account is questionable. These events took place during the reign of Romanos Lekapenos, but their exact dating is unclear. Mas'ūdì claims that the invasion of the 'Turks' took place in the Hijri year 320 or a little bit later, but a few verses later he moves this event to 332 . It is hard to resist the impression that he has combined two separate facts in his account, namely two events known to Byzantine sources, dated to 934 and 943. ${ }^{118} \mathrm{~A}$ circumstance conducive to such a mistake was the fact that both expeditions ended in the same manner: the invaders reaching Constantinople.

116 Josef Marquart: 'Andalus' (1903, 63).

117 English translation by Sprenger $\left(1841,45^{2}\right)$. Cf. al-Mas'ūdī, Les Prairies, II, 64; Pellat 1962, 179; Marquart 1903, 63; Konovalova 1999, 6-7; Konovalova, Perkhavko 2000, 148. ibn alAthir also briefly mentions the attack on Walandar (12th-13th century.). Cf. Konovalova, Perkhavko 2000, 149 .

118 On the 934 invasion: Th.Cont., 422-423; Georg.Mon., 913-914; Sym.Magist., 136.69 (p. 334); Io.Scyl., 228; Wortley 2010, 220-221; On the 943 invasion: Th.Cont., 430-431; Georg.Mon., 917; Sym.Magist., 136.77 (p. 337); Io.Scyl., 231; Wortley 2010, 223. Cf. Moravcsik 1970, 55-56; Antonopoulos 1993, 258-261. Both invasions took place in April, which raises suspicions that what we are dealing with here is a topos, which served to show the wickedness of the invaders, ready to attack the empire close to Holy Week and Easter. 
Josef Marquart was among the first researchers to carry out a critical analysis of Mas'üdì's data. The German researcher assumed 934 to be the date of the invasion of these 'Turkish peoples', which meant connecting the events from Walandar with the first Magyar expedition. ${ }^{119}$ Marquart also convincingly demonstrated that the coalition of invaders consisted of two, rather than four ethne. Their having multiplied can be explained by the fact that the author of Meadows of Gold used a number of different sources that contained different variants of the names of both peoples. ${ }^{120}$ Walandar is in all likelihood Debeltos $(\Delta \varepsilon \beta \dot{\varepsilon} \lambda \tau \circ \varsigma)$, a fortress located on the Bulgarian-Byzantine frontier. Its location by the Black Sea proves that the concentration of allied armies had to take place near the lower course of the Danube. This would suggest the participation of the Pechenegs in the expedition, because if the Magyars invaded on their own, the route of the expedition would most likely have been different. It would have led towards Constantinople through today's Serbia, Bulgaria (near Sofia) and Thrace. ${ }^{121}$

Despite their rather widespread acceptance, Marquart's findings have been questioned, at least in part. Carlile A. Macartney assumes that among the peoples mentioned by Mas'üdī, the name Bağnà includes the Bulgarians as well. On the basis of this statement, Macartney claims that the battle of Walandar took place in 917 and was a part of the Bulgarian-Byzantine war described above, in which the Pechenegs are said to have fought for Simeon. The presence of the Magyars in Mas'üdì's narrative is supposedly the result of the author's merging two separate events: a joint Bulgarian-Pecheneg attack on the border fortress (917) and a Magyar invasion which reached as far as to Constantinople (934). ${ }^{122}$ Macartney's concept, although interesting, is based on a philological premise that is considered false. The British researcher identified the ethnonym Bağnà with the Bulgarians on the basis of the supposition that it is a distorted version of the ethnic name Borğan. ${ }^{123}$ However, this kind of reasoning has no philological or palaeographic justification, ${ }^{124}$ which deprives Macartney's hypothesis of its foundations.

A few years later, Vladimir Minorsky proposed that the name Nükardah may actually refer to the Novgorodians, or more precisely to Novgorodian outcasts,

\footnotetext{
119 Marquart 1903, 63-64. For other interpretations of al- Mas'ūdī's report: Macartney 1930; Bozhilov 1930, 48-53; Runciman 1988, 106-109; Kniaz'kii 2003, 15-16.

120 Marquart 1903, 65-68.

121 Marquart 1903, 69-71.

122 Macartney 1930.

123 Macartney 1930, 162.

124 Cf. Golden 1975, 29.
} 
who lived among the 'Turks'.125 Irina A. Konovalova has recently explicitly referred to his findings. She claims that the attacks on Italy, Muslim Spain and France, which Mas'ūdī generally attributes to a Turkic people in his reports, were mainly carried out by the Nükardah. ${ }^{126}$ The researcher also believes that the Rus' were active in the Lower Danube region and Bulgaria as early as the late 9 th century, ${ }^{127}$ and were likely to have travelled through this area on their way to Constantinople. It is difficult to question this last claim, but it does not explain why the Mas'ū $\overline{\text { in }}$ used the name of one Rus' sub-group instead of the general term 'Rus'. Konovalova explains that this resulted from increasing knowledge in the Muslim world about the political and ethnic relations in Rus.' ${ }^{128}$ This argument is not convincing, however, because Mas'ūdī included Nūkardah among the 'Turkish peoples', so he was not aware of their alleged Rus' ancestry.

Despite the fact that more than 100 years have passed since their first publication, Marquart's findings are still widely accepted. It should be noted, however, that they do not explain all the unclear points in Masudi's account. This is because the German researcher seems to ignore the double dating of the expedition of the 'Turkish peoples' and the accompanying events. If Mas' $\mathrm{u} d \overline{1}$ combined two Magyar invasions, one of which (or perhaps both!) was said to be aided by the Pechenegs, the question arises as to whether his account is not in fact a conflation of information concerning a number of attacks carried out by nomadic peoples on Byzantium, the only common feature of which was the fact they occurred during Romanos Lekapenos's rule.

A further question should be asked here: what prompted the Magyars and Pechenegs to cooperate? This question is all the more justified because this expedition was probably not a retaliatory action. Marquart believed that such a military undertaking would have been recorded by Byzantine sources. He also believed that information about a dispute between the Magyars and the Pechenegs arising from the poor treatment of a Muslim merchant from Ardābil was a distorted echo of past conflicts between these two ethne on the Black Sea steppe. ${ }^{129}$ The German scholar also claimed that information about peaceful relations with the Alans and Khazars only concerns the Magyars, and can hardly be applied to the Pechenegs. ${ }^{130}$

\footnotetext{
125 Minorsky 1958, 113, 16o (note 2).

126 Konovalova 1999, 11-12.

127 Konovalova 1999, 12.

128 Konovalova 1999, 15; Konovalova, Perchavko 200o, 153-157.

129 Marquart 1903, 71-74.

130 Marquart 1903, 74.
} 
Indeed, the joint invasion carried out by these two nomadic peoples was most likely not preceded by Byzantine provocations in the border region. It can be assumed that minor incidents not recorded in sources were probably a normal phenomenon in border areas. The problem is that Walandar, if identified as Debeltos, was on the Byzantine-Bulgarian border, which in practical terms makes it impossible for the expeditions against the Pechenegs or Magyars to have been organized by the fortress garrison. Moreover, undertaking any wide-scale expeditions against the steppe-dwellers, especially in the 930s, was not in the interests of Byzantium. Such behaviour on the part of the Empire would have been incompatible with the direction of foreign policy being pursued during Romanos Lekapenos' reign, the basic aim of which was to avoid a simultaneous conflict with two enemies. After calming relations with Bulgaria, the emperor could afford to concentrate all the state's energies to fighting the Arabs. As a result, Byzantium was soon able to take the initiative militarily, which ultimately resulted in the successful retaking of Melitene in 934. ${ }^{131}$

The incursion described by Masudi can potentially be seen as the result of the diplomacy of a third-party state. The fact that knowledge about events which took place along the northern borders of Byzantium could reach rather distant parts of the Arab world seems quite amazing. The chronological concurrence of the invasion of the 'Turkish peoples' and the Byzantine offensive, the crowning achievement of which was the conquest of Melitene, is also quite very curious. Romanos Lekapenos' problems along his state's north-western border were also an extremely fortunate circumstance for the Hamdanids who ruled in Mosul and Aleppo. Such tempting hypotheses are not, however, the sole explanation for the Muslims' interest in the events that took place in distant lands. After all, Muslim merchants trading in Eastern Europe were most likely the primary medium for spreading knowledge about these parts. The Byzantine-Arab conflicts of the mid-1oth century, during which the Islamic world was put on the defensive, were most likely conducive to interest in accounts in which the infidels were defeated by armies comprised in part of Muslims. ${ }^{132}$ In Mas'ūdì's works, we find elements of jihadist ideology in the form of stories about the numerous followers of Mohammed who took part in the expeditions of the 'Turks', but only those waged against infidels, as well as information about attempts to convert Byzantine soldiers to the 'faith of the prophet'.

The attack described by Masudi need not have been, and probably wasn't, the result of diplomatic intrigues on the part of the Hamdanid dynasty, but

131 Ostrogorski 1967, 236; Treadgold 1997, 481-3.

132 Cf. El Cheikh 2004, 165-167. 
was most likely an ordinary looting raid. Debeltos-Walandar was not only a border fortress, it was also an important commercial centre and the seat of the bishopric. The city's wealth provided sufficient reason to attack it. However, if the raid (or raids) in question was a simple attack, free of any hidden agenda or political motivations, the question inevitably arises if there was a need to form an entire coalition of attacking forces. If it were merely a looting raid, inviting others to cooperate would seem senseless, as it would necessitate a division of the booty. The only justification would be the Magyars' fear that the Pechenegs would use the absence of their main forces as an opportunity to invade their territories. Such concerns would not be groundless, as evidenced by the events of the 89 os, though at that time, the Pechenegs were searching for new territories, and were much more dangerous than in the first third of the 1oth century. Yet the potential threat of an attack on a smaller scale than their catastrophic incursion in the late 9th century did indeed exist. It is also worth noting that the Magyar expedition of 934, which is usually associated with the events described in Mas'üdi's account, is considered by Byzantine sources to be the first Magyar invasion of the Empire. ${ }^{133}$ It is therefore possible that this change in the direction of the Magyars' expansion prompted them to attempt to mitigate the threat of an attack by their former enemy by proposing a joint invasion of the Balkans. They also knew that once Byzantium realized it faced a new threat, it might call on the Pechenegs for support.

However, one key fact renders such an interpretation problematic. Byzantine chronicles do not mention the involvement of the Pechenegs in the Magyar expeditions of either 934 or 943 . This silence is telling, because every invasion that reached the walls of Constantinople was accompanied by diplomatic negotiations. It is unthinkable that imperial officials would have completely ignored another participant in the expedition when drawing up a peace agreement with Magyars. Of course, it is very possible the Pechenegs were less active in the final stage of the invasion or had completely withdrew their main forces after the conquest and pillaging of Walandar. Only smaller Pecheneg units would have reached the capital of the Empire, acting as hostages and guaranteeing the peaceful intentions of their compatriots.

Another hypothesis, one that is equally probable, can be contrasted with this first one. If Mas'ūdī merged two separate pillaging Magyar expeditions in

133 After their migration to Pannonia, the Magyars directed their looting-expeditions mainly to the west. In March 933 they were severely defeated by Henry I, king of East Francia, in the battle of Riade on the Unstrut River (an unidentified site somewhere in northern Thuringia). This defeat seems to have prompted the Magyars to make Byzantium the target of their future predatory expeditions. Cf. Bíró, Langó 2013, 284-285, 311. 
his work, it cannot be ruled out that he also included a third one, one chronologically close to these first two. Such an expedition might simply not have had such a spectacular conclusion, reaching its culmination point in the Byzantine borderlands. According to the chronology of the Rus' chronicles, in 944 the Pechenegs aided an expedition by Igor against the Greeks. However, this campaign was cut short by the diplomatic efforts of Constantinople, which led the Rus' prince to make peace and withdraw. ${ }^{134}$ Before his retreat, Igor was said to have ordered the steppe warriors supporting him to attack and pillage Bulgaria. It is possible that the Pechenegs carried out this mission, first ravaging Dobrudja, ${ }^{135}$ then clashing with imperial troops at the Byzantine border, and finally, taking and plundering Debeltos. Mas'ūdì's account would thus describe three separate events that took place during the last decade of Romanos Lekapenos' rule (934-944): two Magyar invasions which reached Constantinople and a Pecheneg expedition during which part of western Bulgaria and the Byzantine border region were ravaged.

Regardless of which hypothesis one accepts, the presence of the Pechenegs in Walandar itself should be considered probable. They stood before the fortress either in 934 as allies of the Magyars or a decade later on their own. Mas'ūdì's description of the battle seems credible. The combat methods used by the invaders did not differ substantially from standard steppe practices. ${ }^{136}$ On the other hand, data on the size of the imperial army and the number of casualties it sustained raises doubts. It is difficult to believe that Byzantium was able to concentrate such a large number of troops (65,00o men) in such a short period of time. All the more so given that its mobilization capabilities were significantly reduced by its involvement in fighting against the Syrian Hamdanid emirate. ${ }^{137}$ The description presented earlier of the events of the

134 Cf. below.

135 Bozhilov 1973, 6o; Dimitrov 2011, 228-229; Polovoi 1958, 138-147; Madgearu 2013, 26. The Pecheneg invasion is said to be evidenced by the 'zhupan Dimitr' inscription, discovered in Mircea Vodă, near Constantia. Its meaning, however, is quite unclear. Igor's expedition against the Greeks and the subsequent Pecheneg invasion of Dobrudja are dated to 943 by Dimitrov and Polovoi. This chronology led the latter scholar to adopt the rather dubious interpretation that Igor was at the head of an entire coalition of 'peoples of the north', which, apart from the Pechenegs, the Rus' and Slavic tribes, also included the Magyars. However, the reasoning of the Russian researcher is noteworthy, as it may reflect the manner of thinking of Mas'ūdī, who due to a chronological coincidence, may have combined two separate expeditions.

136 Cf. Chapter 4.3.

137 Ostrogorski 1967, 236; Treadgold 1997, 481-3. According to the estimates of contemporary scholars, in the 1oth century the Byzantine army consisted of just over 80,000 soldiers (Cheynet 2006b, 164-165). However, for logistical reasons, the Empire never operated with 
year 917 showed that a more extensive offensive against Simeon required diplomatic efforts aimed at tactically freeing up troops stationed in the East. It was only after the signing of a peace treaty with the Arabs that these forces could be transferred to the Balkan region. This example shows that Romanos Lekapenos, while militarily engaged in Syria, could not have immediately sent such a strong army to defend Walandar. Thus, the Byzantine army that faced the nomad hordes not only did not outnumber them, but was even significantly smaller in numbers. However, Mas'ū nomads should be approached with caution. ${ }^{138}$ The imperial army's losses were certainly substantial, but Mas'ūdì's story about the tremendous number of dead and their bodies being used by the attackers to climb the walls of the besieged city was most likely a product of his informants' vivid imaginations.

Marquart is wrong, however, when he claims that it was only the Magyars who established good relations with the Khazars. Although the Pechenegs' encroachment on the Black Sea steppe greatly affected the functioning of Pax Chazarica, with time, the rulers of the khaganate have come to terms with the consequences of this migration and established a working relationship with their new western neighbour. Seeking to improve relations with a recent enemy, especially when it was powerful, would not have been an unusual situation.

The expedition of 934, regardless of whether or not the Pechenegs took part in it, points to a change in Byzantine-Magyar relations. This people, who had previously acted as an ally of Constantinople, unexpectedly proved that they were ready to take hostile action against the Empire. Less than a decade later a second invasion took place, which again proved that the Balkan provinces of the Byzantine Empire were not completely safe. Of course, the new enemy did not threaten the interests of the Empire as much as the Bulgarian state had during the reign of Tsar Simeon. However, the expeditions of the Magyars, especially when accompanied by the Pechenegs, could have been extremely troublesome. The latter people proved that they posed a threat not only to the southern Crimean estates of Byzantium, but also to its Balkan provinces. During the reign of Tsar Peter, the Bulgarian state was unable or unwilling to act as a buffer to protect the Empire from the armed incursions of the nomads. ${ }^{139}$ The

all its forces. Moreover, in the 1oth century, despite its division into Eastern and Western parts, Byzantium had only one army capable of resisting a mass invasion. Therefore, before a major expedition, the troops of the East and the West usually joined forces.

138 However, Mas'üdì's information is sometimes used to estimate the mobilization potential of the peoples who supposedly participated in the Battle of Walandar. Cf. Zimonyi 2014a, $176-177$.

139 I do not intend to enter into a discussion here about what Bulgaria was during the reign of Tsar Peter. Regardless of its condition, Byzantine diplomats, especially after the 
events of 934 were therefore the first in a series of events that raised Byzantine politicians' awareness of the Pechenegs' significance, and, over time, forced them to change their attitudes towards this people.

\subsection{The Pechenegs as Allies of the Byzantine Empire}

The events of 941-944, which began with an unexpected Rus' invasion of Byzantium, would be a turning point. ${ }^{140}$ Its causes have long been the object of speculation. Older historiography pointed to disagreements that were likely to have stemmed from differences in the two sides' interpretations of the provisions of the first Rus'-Byzantine treaty, traditionally dated to 912. It was also assumed that improved relations with Bulgaria following the peace of 927 changed the attitude of the court in Constantinople to the Rus'. The Rurikids were no longer needed as a potential ally of the Empire against the Bulgarians. Finally, it was assumed that Rus' had resumed its expansion in the Black Sea region after a long pause during which it extended its rule over a number of Slavic tribes. On the eve of its military campaign against Byzantium in 941, Rus' is said to have expanded onto the Taman Peninsula. ${ }^{141}$

The actions of the Rus' in this region would seem to have been connected with their planned attack in 941. However, the circumstances surrounding these events were much more complicated. From Khazar sources (written in Hebrew), we know that the Rus' appeared on the peninsula as part of a diplomatic arrangement with the Byzantines. ${ }^{142}$ This was an attack, above all, on the interests of the Khazar state and was carried out in retaliation for the persecution of Christians in the khaganate. For the sake of clarity, this oppression, in turn, had been in retribution for the earlier persecution of Jews in Byzantium, in particular, Romanos Lekapenos' forcing them to convert to

experiences of the decade 934-944, must have seen that it did not provide protection against armed penetration by the 'northern and Scythian peoples'. Of course, this kind of observation did not have to and probably did not lead to the conviction that it was immediately necessary to liquidate the Bulgarian state. According to Skylitzes, Nikephoros Phokas accused Peter of failing to react to the invasions of the Magyars. Io.Scyl., 276-277; Wortley 2010, 265. John Zonaras cites the sharp response of the Bulgarian Tsar to Phokas's accusations. Io.Zon., 513. For one reason why Peter let the Magyar expeditions through: Zlatarski 1927, 541-544; Dimitrov 1998, 72-77; Mladjov 1998, 120-123.

140 PVL 1, AM 6449 (941), col. 44-45.

141 Levchenko 1956, 139; Łowmiański 1973, 201-202; Litavrin 2000, 69.

142 Golb, Pritsak 1982, 114-119, 136-137. 
Christianity in the early 930 os. ${ }^{143}$ The first attack by Rus' on the Khazar possessions in Taman more precisely, on the city of S-m-k-r-ts, must have taken place at the end of the 930s. ${ }^{144}$ The attackers initially managed to move onto the peninsula, but were later defeated by a Khazar commander named Pesah, who reclaimed this territory and forced them to attack the Byzantine Empire.

In 941 the Rus' ${ }^{\prime 15}$ landed their forces in Bithynia and plundered its coasts with impunity for four months. Finally, after being cornered by the Byzantine army and suffering several defeats, the Rus' were forced to retreat. Although they managed to escape onto the Black Sea, they encountered a Byzantine fleet commanded by Theophanes near the Thracian coast. With the aid of 'Greek fire' he managed to destroy many Rus' ships. ${ }^{146}$ Despite this defeat, Igor attacked Byzantium again soon afterwards. This time, however, apart from a large Slavic-Varangian contingent, he also brought with him the Pechenegs. ${ }^{147}$ Their involvement made the expedition of 944 very dangerous for the Empire, as it posed a threat to the capital both from land and sea. The allied armies reached the Danube, where their invasion forces probably split into two groups: the Pechenegs would march to Constantinople through Bulgaria, while the Rus' would sail to the Bosporus along the western shores of the Black Sea. The Byzantine Empire's military involvement in Mesopotamia, where John Kourkouas enjoyed spectacular victories, ${ }^{148}$ had left it without an army capable of resisting the invaders in the west; nor could it count on the help of any allies. Its diplomatic influence remained the imperial court's only weapon.

143 Łowmiański 1973, 198-199; Zuckerman 1995, 255-256; Shepard 1998, 30. The persecution initiated by Romanos Lekapenos was supposed to have resulted from the failure of the Christian mission in Alania, from which the Christian clergy were expelled.

144 Shepard 1999a, 266; 2006, 26.

145 According to Khazar sources, the commander of the Rus' expedition, called Helgu (or Oleg in the Slavic version of this name), withdrew after the defeat to the east and died in Persia (Frs). Constantin Zuckerman links this information with Miskawajhi's account of the Rus' expedition to the lands of the Berdaa on the Caspian Sea. Initially, the invaders were successful, but later almost everyone was killed, including the commander. They fell victim to dysentery and successful attacks by one of the local rulers. According to Zuckerman, Miskawajhi gave the last details about the expedition led by Helgu/Oleg, who after suffering a defeat on the Black Sea to the Byzantines, made his way to the Caspian Sea, where he died. Zukerman identifies the aforementioned Helgu with Prince Oleg, known from Rus' chronicles, who, according to Rus' tradition, died in quite unclear circumstances. In 941 the empire was supposedly then attacked by Igor and Oleg. After his initial failures, the young prince most likely abandoned the old prince and returned to Rus'. Golb, Pritsak 1982, 118-119; Miskawajhi, 67-69. Cf. Zuckerman 1995, 256-268.

146 PVL 1, AM 6449 (941), col. 44-45.

147 PVL 1, AM 6452 (944), col. 45.

148 Ostrogorski 1967, 237; Cheynet 2006, 30; El Cheikh 2004, 165. 
This diplomacy followed two paths. Agents of Constantinople attempted to persuade the Pechenegs to withdraw from their alliance with Igor by offering generous gifts. Igor, in turn, was offered a tribute greater than that collected by Oleg and the renewal of the previous peace treaty, which also regulated the terms of trade. ${ }^{149}$ The Kievan prince decided to accept the Byzantine offer and halt his march. Then, having ordered the Pechenegs to plunder the Bulgarian lands, he set off on his way back to Kiev. ${ }^{150}$

The expeditions of 941 and 944 were the last in a series of events that made the Byzantine elites aware of the political importance of the Pechenegs. The peace that prevailed in their relations with Rus' between 911 and 941, as well as the pacification of relations with the Bulgarian state had turned the attention of Constantinople's diplomats away from the Black Sea steppe zone. Improved relations with both states facilitated the Empire's eastward expansion, indirectly helping to secure its borders in Asia Minor, and thus promoted Byzantine interests; however, the safety of the northern and north-western borders was not likewise secured. Meanwhile, the events of the first half of the 1oth century proved that the Byzantine Empire needed an ally in this region to help it deal with recurring threats. It is possible that in the late gth century the Magyars played such a role. However, the year 896 changed this situation. The court in Constantinople initially failed to come to terms with this fact, as evidenced by its attempts, probably no later than 907, to encourage the Magyars to return to their previous homeland. These attempts by Byzantium to cooperate with the Magyars' former conquerors, dating back to 917, did not bring the expected results. Instead, it appears to have contributed to a spreading of mistrust between Byzantium and the Pechenegs. A political vacuum was created by the departure of the Magyars. Initially, this did not imperil Byzantine interests in the region, but the 93os brought new threats. The first was a change in relations with the Magyars, who had transformed from a client into an independent ethnos ready to take hostile action against the Empire. The Rus', whom Romanos Lekapenos wanted to see as the military arm of Byzantium in the Black Sea region, proved to be a dangerous and troublesome partner. Attempting to use them against the Khazars appears to have been a serious political mistake, as shown by the course of events, which ultimately resulted in this recent ally becoming a dangerous enemy. A permanent Rus' presence in Tmutarakan threatened over the long term the security of Byzantine possessions in Crimea. Despite its initially negative consequences for the Empire, Pesah's victory should be considered an event that helped restore equilibrium

149 PVL 1, AM $645^{2}$ (944), col. 45-46.

$15^{\circ}$ PVL 1, AM $645^{2}$ (944), col. 46; AM 6453 (945), col. 46-54. 
along the northern shores of the Black Sea. The invasion of 941 rendered the atmosphere in Constantinople reminiscent of that which emerged after the Rus' expedition of 860. ${ }^{151}$ These incidents were of particular concern to Bulgaria, which did not want to act as a buffer to protect the outskirts of the Empire's capital. The events of 934-944 were therefore a reminder of the importance of the Lower Danube area and the Black Sea steppe for the safety of Byzantium, thus highlighting the role of the Pechenegs.

When was a second, more permanent Byzantine-Pecheneg alliance concluded? This had probably already taken place when Constantine VII was editing his De administrando imperio. The years 949-951 should therefore be regarded its terminus ante quem. The information provided by the learned emperor in chapters one to eight seem to indicate that relations between the two political partners were very tense at the time. Constantine viI writes about the need to send an imperial diplomatic agent to the Pechenegs every year with appropriate gifts and letters, and of ensuring the nomads' loyalty by securing hostages from them, who were detained in Constantinople under the care of a government minister. We also read here about how relations with Pecheneg leaders were established and other diplomatic rituals. ${ }^{152}$ It seems, therefore, that the date when the alliance was established can be safely moved back a few years. It is possible that it was formed near the end of Romanos Lekapenos' reign, i.e., in 944. This would mean that the court in Constantinople, as it was deciding whether or not to renew the treaty with Rus', was also holding political negotiations with the Pechenegs aimed at forming an alliance that could help secure the agreement they were planning to sign with the Rurikids. Since we know that this followed the same procedure as Byzantine diplomacy in 971, when a peace agreement with Sviatoslav was accompanied by a renewal of a political alliance with the Pechenegs, it can be assumed that twenty-seven years earlier the case was no different. However, it seems more probable that the idea of an alliance with the nomads was conceived by Constantine Porphyrogenitus, who strongly emphasized its importance in De administrando imperio, especially as a tool to stop the Rus', Magyars and Bulgarians. The alliance with the Pechenegs should therefore be dated back to the beginning of his independent rule, i.e., around $945{ }^{153}$

In view of the findings presented above, a question arises as to what kinds of changes may have arisen in the relationship between the Pechenegs and

151 This was surely both surprising and dangerous. Liutprand., v 15 (p. 137-139); Georg.Mon., 914-916. Cf. Franklin, Shepard 1996, 113-114; Shepard 1999a, 269.

152 DAI, I-VIII (pp. 48-57).

153 Shepard 1999a, 273; Paroń 2007a, 103-105. 
Rus' as result of improved relations between the nomads and the Byzantine Empire. Did the end of Pecheneg attacks on Kherson coincide with a resumption of armed incursions against Rus'? No such changes were recorded by the Rus'. Although Constantine Porphyrogenitus writes about the possibility of the Pechenegs attacking the Rurikids' possessions, and later, about the devastation they wreaked while Rus' armies were away on a military expedition, ${ }^{154}$ Igor's death in 945 resulted in a 20-year break in Rus' expansion. Constantine VII also notes that the nomads maintained trade relations with the inhabitants of Rus.' ${ }^{155}$ This last fact seems to prove that in the mid-1oth century relations between the Pechenegs and Kiev could have been quite good, or at least good enough not be dominated by military confrontation.

A change that would severely affect the Pechenegs' situation occurred in the latter half of the 96os. The Primary Russian Chronicle states that Sviatoslav I assumed power over Kievan Rus' in $964 .{ }^{156}$ Virtually all of his reign was characterized by dynamic expansion, the first victim of which was the Khazar Khaganate. Rus' chronicles report that the Khagan's army was defeated, allowing the Kievan prince to seize the fortress of Sarkel, and most likely Itil, the capital of the Khazar state. ${ }^{157}$ In that same year (965), Rus' also defeated the Kasogians and Yassians. The first people are identified as the Cherkess, who inhabited the Taman Peninsula, and the latter as the Alans, who lived in the North Caucasus. ${ }^{158}$ Ibn Hawqal, a 1oth-century Arab author, provided additional information about these events:

At the present time, the Rūs have left nothing to the Bulghār, Burtās and Khazars but a few worthless ruins. They fell upon them and looted everything, obtaining in their territories more than they could have hoped for. ${ }^{159}$

154 DAI, II (pp. 48-51).

155 Cf. Chapter 4.2 of the present book.

156 PVL 1, AM 6472 (964), col. 64-65.

157 PVL 1, AM 6473 (965), col. 65. Cf. Golden 1980, 82; 200o, 297.

$15^{8}$ PVL 1, AM 6473 (965), col. 65. Cf. Artamonov 1962, 426; Pletneva 1976, 71.

159 Quote from: Lunde, Stone 2012, 178. Cf. Dunlop 1954, 241-242; Grekow 1955, 480. Rus' chronicles and ibn Hawqal seem to describe the same event. Differences in dating (Hawqal claims that the Rus' invasion took place in 968/9) incline some researchers to accept the hypothesis of Sviatoslav having undertaken two expeditions against the Khazars. Cf. Kalinina 1976, 100 (the researcher adopts the following sequence of expeditions: 965 - invasion of the White Tower-Sarkel, the Kasogians and Yassians; 967 - an expedition against the Danube Bulgarians; 968/9 - second invasion of Khazaria, and the conquest and destruction of its main cities); Novosel'tsev 1990, 225-227 (accepts T.M. Kalinina's reasoning). Most scholars, however, believe that there was only one Rus' 
The Muslim writer is most likely confusing the Volga Bulgars with the Danube Bulgars, who were also victims of Sviatoslav's aggression, though not in $965 .{ }^{160}$ However, it is true that Itil and Samandar, the main centres of the Khazar state, were indeed devastated. The last fact and the attack on peoples of the Caucasus subordinate to the khaganate signalled the definitive dismemberment of the Pax Chazarica. Although the Pechenegs had inflicted a serious blow to it in the late 9th century when they occupied the Black Sea steppe, later events evidenced the continued vitality of the Khazars. In his description of the return of Rus' troops from the Caspian expedition of 913-914, Mas'ūdì shows that the khaganate still controlled the Volga route. Igor's raiding forces learned this in a dramatic way when they were attacked by Muslim mercenaries hired by the Khagan and his allies, the Burdas and Volga Bulgars. ${ }^{161}$ The victory of Pesah over the Rus' commander Oleg-Helgu (HLGW) described above also confirms the strength of the khaganate in the first half of the 1oth century. Although the Bulgars began their struggle for independence in the early 92os, similar processes were not yet present in other parts of the Empire. Joseph ben Aaron, the khaganate's last ruler, still controlled a vast territory. ${ }^{162}$ Ibrahim ibn Yaqub, whose account was probably written in the mid-96os, and therefore just before the fall of Khazaria, also mentions its inhabitants among the most significant peoples of the north. ${ }^{163}$

The collapse of the khaganate, therefore, occurred suddenly. Sviatoslav's aim, apart from seizing spoils, was most likely to eliminate it as a competing political and commercial centre. Igor's successor would subject the Viatichi, the last East Slavic tribe to still recognize the sovereignty of the khaganate, to his rule. He additionally took control of at least a part of the Don, a major transportation route. This seems to be confirmed by the fact that the Rus' established themselves in Sarkel, while there is less certainty about their permanent presence in Tmutarakan. ${ }^{164}$ Such territorial acquisitions made it

expedition, which, moving along the Volga, first destroyed the Burdas, then captured and sacked Itil, and then attacked the northern Caucasus, finally sailing via Kerch Strait and the Sea of Azov into the Don. Sailing upstream, they reached Sarkel, which they also conquered. Cf. Bartol'd 1963, 851; Artamonov 1962, 427; Dunlop 1954, 243-244; Gadlo 1979, 207; 1994, 56-57; Golden 1980, 82.

16o Marquart 1903, 474-475; Bartol'd 1963, 85o-851; Kalinina 1976, 96; Novosel'tsev 199o, 225.

161 Cf. above, note 103.

162 Perepiska, 81-83, 98-102. The area controlled by Khagan Joseph allegedly stretched over an area that took four months' travel to cross.

163 Ibn Yaqub, 52; Mishin 1996, 19 o.

164 The scale of Sviatoslav's territorial acquisitions and length of possession is unclear. From the information provided by ibn Hawqal, it seems that he took over all the lands of the Khazars and the peoples subordinated to them. However, a literal reading of the 
possible to reduce traffic on the route 'from the Varangians to the Greeks', which was controlled by the Pechenegs along parts of the Lower Dnieper.

However, another consequence of the fall of the Pax Chazarica is equally important. It has been repeatedly mentioned that the raison d'état for the khaganate had been to organize and secure the development of trade. The political system built to fulfil these tasks limited the migration of the warrior nomads who came from Inner Asia to the Volga region. Although in the late gth century the Khazars and their allies did not manage to stop the Pechenegs from moving onto the Black Sea steppe, this did not mean that their system had been dismantled. It was not until the invasion in 965 that the barrier protecting them from attacks of the nomads who lived in the Volga region was destroyed. The situation that ensued would put the Pechenegs in serious danger ${ }^{165}$ as they were about to be forced to fight a bitter conflict with their old enemies, the Uzes, which would significantly weaken their position on the Black Sea steppe.

It is unclear whether the Pechenegs realized how important the buffer the khaganate provided was to their security. The exact shape of their relations with the Khazars in the 1oth century is also unknown. In the Schechter Text dated to the mid-1oth century, the Pechenegs were not listed among the Khagan's allies. ${ }^{166}$ In De administrando imperio, an almost contemporary source, Constantine Porphyrogenitus did not classify them as enemies of the Khazars who might attack them. ${ }^{167}$ It is therefore likely that in the first half of the 1oth century, relations between the Pechenegs and Khazars improved. The Pechenegs were most likely involved in a system of trade relations established

information supplied by the Arab writer is not justified. Most researchers assume that the Rus' prince conquered only part of the attacked lands. Cf. Łowmiański 1973, 217 (seizure of Tmutarakan); Artamonov 1962, 429, 430-431 (Sviatoslav conquered only the Don region, to Kerch Strait); Gadlo 1979, 57; 1994, 207 (assumes that Sviatoslav did not conquer any territories apart from Sarkel. His reaching the Don region, the Volga region or the northern Caucasus was allegedly prevented by the Pechenegs). For a different interpretation: Novosel'tsev 1990, 224, 227 (extensive territorial acquisitions, among which there were also areas around the Volga estuary, allegedly controlled by the Rus' at the beginning of the $980 \mathrm{os})$. However, there are researchers who date the strengthening of the Rurikids' presence in Tmutarakan only to the 98 os. Cf. Chapter 4.2 of the present book, footnote 134 .

165 Łowmiański 1973, 217 (one cannot accept his theses. The fall of the khaganate did not embolden the Pechenegs, as much as it struck a blow to their interests); Golden 1980, 85 (he claims that Byzantium was most severely affected by the fall of the khaganate); Romashov 1999, 35 .

166 Golb, Pritsak 1982, 120-121.

167 DAI, X-XII (p. 62-65). 
by the Khazars, ${ }^{168}$ which cannot, however, be regarded as proof of their political dependence on the khaganate.

The position taken by the Pechenegs during the events of 965 therefore remains a mystery. According to some Russian researchers, on his expedition against the Khazars, Sviatoslav had to secure his rear by forming an alliance with the Pechenegs, which is said to be evidenced by the fact that the nomads took part in the attack on Khazaria. ${ }^{169}$ This interpretation is allegedly supported by Miskawajhi (932-1030), a Persian historian and philosopher. In his world history, The Experiences of Nations, he recorded an invasion of Khazaria in 965 supposedly carried out by some 'Turks'.170 This extraordinary chronological coincidence suggests that they acted in collusion with Rus', or that they simply spontaneously took advantage of the khaganate's weakened state. However, it is the identity of the aggressors that is crucial here. Most researchers rightly assume that they were most likely not the Pechenegs, but the Uzes, ${ }^{171}$ known to have been potential enemies of the Khazars in the mid1oth century. ${ }^{172}$ The Pechenegs probably took a neutral, cautious attitude towards the events of 965 . Perhaps they assumed that the khaganate would be able to overcome Rus' aggression, as they had many times before. The Pechenegs most likely only became concerned as a result of the consequences of the fall of Khazaria. This included, above all, Sviatoslav establishing settlements in Sarkel, on the eastern borderlands of Patzinacia. The presence of the Rus' in the valley of the Don was most certainly seen as dangerous and provocative. The collapse of trade relations, which most likely followed the fall of the Pax Chazarica, would also have negative economic consequences. The Pechenegs benefited from this trade, so they must have suffered from its absence as well. Concerns about Rus' expansion may have prompted the nomads to attempt an assault on Kiev in 968 .

This was one of a number of episodes that had their start three years earlier, in the highly eventful year of 965 , when Bulgarian emissaries arrived in Constantinople to demand the tribute paid by previous basileis. In response, Emperor Nikephoros Phokas had the emissaries publicly ridiculed and flogged. Such a highly undiplomatic gesture was certain to lead to armed conflict with Bulgaria. Phokas himself did not take serious military action, however, as this

\footnotetext{
168 Cf. Chapter 4.2 of the present book.

169 Tolstov 1948, 252; Pletneva 1958, 215; Kalinina 1976, 94; Gadlo 1979, 57; 1994, 207 (Sviatoslav made an alliance not only with the Pechenegs, but also with the Uzes).

170 Miskawajhi, 223. Miskawajhi's information is also repeated by ibn al-Athir, who was writing in the 13th century. Cf. Dunlop 1954, 244.

171 Artamonov 1962, 431; Golden 1980, 83 (note 261); 1972, 77-80; Novosel'tsev 199o, 225.

172 DAI, X 3-4 (p. 62).
} 
would have forced him to cease his military activity in the east. He merely destroyed a few border fortresses, and entrusted Sviatoslav with the task of persecuting Bulgaria. ${ }^{173}$ The Byzantine Emperor's choice of ally is quite puzzling. Above all, it begs the question why he did not choose the Pechenegs, who could easily have attacked Bulgaria due to their geographical proximity. Moreover, they were tied by a political alliance to the Byzantine Empire and did not appear to have any greater political ambitions. The Emperor's behaviour is quite telling, as it reveals the position of the Pechenegs among the allies of Byzantium at that time. It is clear that the ruler preferred political and military cooperation with the Rus' prince rather than with the nomads, who, although militant, were seen by him as being too wild and unpredictable. Nikephoros Phokas's choice helped Kiev and Constantinople establish a closer relationship than that which had previously been achieved through the regent Princess Olga. During the reign of Constantine Porphyrogenitus, she had visited the court in Constantinople and been baptized there. ${ }^{174}$ Her visit increased the chances for consolidating the peaceful relationship between the two countries. ${ }^{175}$

However, it soon turned out that the hopes of Byzantine diplomats were misplaced. Sviatoslav readily complied with the request of the basileus, and in 967 launched his first attack on the Balkans, but after his victory he did not intend to leave Bulgaria, choosing Pereiaslavets (Little Preslav), situated on the Lower Danube, as his new base of operations. ${ }^{176}$ An attack on Kiev by the Pechenegs in 968 forced the Rus' ruler to abandon this new territory and head for his capital with reinforcements to save the city from the nomads. ${ }^{177}$

173 Ostrogorski 1967, 246; Treadgold 1997, 502; Leszka, Marinow 2015, 181-182.

174 DСв, I, 594-598; PVL 1, Aм 6463 (955), col. 6o-64. The time of Olga's visit (visits?) in Tsar'grad and the time and place of her baptism is the subject of debate. In addition to the traditional chronology according to which the duchess came to Constantinople in 957, some researchers assume that this event took place 11 years earlier, in 946. Cf. Obolensky 200o, 189-19o; 1994a, 56-57; Sakharov 1980, 272-292; Litavrin 1981, 35-48; 1986, 49-57; Nazarenko 1989, 66-83 (the researcher considers both dates to be equally probable); Franklin, Shepard 1996, 142-143 (researchers generally avoid giving the exact date of Olga's visit in Constantinople); Zuckerman 200o, 647-672; Kresten 2000.

175 Ostrogorski 1967, 240-241; Grekow 1955, 479; Litavrin 1986, 57. Apart from hopes for the Christianization of Rus', Olga's visit (visits?) to Constantinople probably also resulted in the fact that Byzantium was using Varangian forces to fight the Arabs. The Rus' warriors were said to be already fighting during the siege of Khadat (955) and during the expedition of Nikephoros II Phokas to Crete (96o-61).

176 On the chronology of Sviatoslav's expeditions to the Balkans: Kryshkovskii 1952, 127-138; Stokes 1962, 44-57; 1962a, 466-496; Sakharov 1991, 122-156; Leszka, Marinov 2015, 184 (researchers suggest that the first of Sviatoslav's expeditions took place in August 968). PVL 1, AM 6476 (968), col. 65-67. 
The Pecheneg expedition is usually assumed ${ }^{178}$ to have been inspired by Byzantine diplomacy. Indeed, if one assumes that the Byzantines sought to drive Sviatoslav out from the Danube region, a Pecheneg attack would have greatly benefited them. However, it is noteworthy that The Primary Russian Chronicle, the only source reporting the invasion of 968 , does not mention any external political influences. It is worth recalling that the Pechenegs' attack was carried out according to their standard military tactics, i.e., while the main Rus' forces were far from Kiev. ${ }^{179}$ Moreover, the destruction of the Khazar Khaganate had aroused concern and irritation among the Pechenegs. Their expedition to the Rus' capital may have been dictated by the desire to weaken Sviatoslav, who was aggressive and posed a threat to their interests. Therefore, it seems that the nomads did not need any external political power to find a reason to attack Kiev.

The loos of the capital city, most likely involving its destruction and the murder of the majority of its inhabitants, including the members of the ruling dynasty, would have been catastrophic for Rus'. However, Sviatoslav managed to arrive in time, defeat his enemies and chase them into the steppe. Soon after his victory, the prince embarked on a second expedition to the Balkans, assumed to have begun in 969 . This time he led an army supported by the Magyars, Bulgarians and Pechenegs. ${ }^{180}$ It is quite surprising that the Pechenegs took part in an invasion aimed at harming the interests of Byzantium. In the light of available source data, one can only offer a hypothetical explanation as to why they were involved. It is important first to estimate how many Pecheneg units were fighting for Sviatoslav. It seems they were not very numerous in size, because they did not constitute the bulk of the Kievan prince's army, but merely provided it with support. Moreover, they represented a people who had recently had been in a violent conflict with Olga's son, so he could not be certain about their loyalty. Observations made in the previous chapter show that it was not a virtue the Pechenegs particularly valued. ${ }^{181}$ Therefore, if Sviatoslav wanted to have full control over his nomad forces, they could only constitute

178 Pletneva 1958, 215-216; Stokes 1962a, 482; Obolensky 200o, 129; 1994a, 58; Sakharov 1991, 123, 132; Wozniak 1984, 310; Treadgold 1997, 503; Spinei 2009, 98. Some scholars, mainly Bulgarian, believe that the invasion of Kiev was inspired by the Bulgarians: Zlatarski 1927, 587-588; Koledarov 1979, 53; Dimitrov 2011, 233-234 (here also a review of views on the subject). Finally, some researchers believe that they were initiated by the dying Khazar Khaganate: Kalinina 1976, 97.

179 This model is discussed by Constantine Porphyrogenitus: DAI, II, IV (pp. 48-53). Cf. Chapter 4.3 of the present book.

18 o Io.Scyl., 288; Wortley 2010; s. 275-276; Io.Zon., 524; Trapp 1986, 33. According to these authors, Sviatoslav brought to the Balkans an army of 308,000 and 300,000 warriors respectively. However, these figures raise understandable doubts.

181 Cf. Chapter 4.4. 
a small fraction of his entire army. Poland's Bolesław Chrobry (the Brave) had most likely adopted a similar approach in his 1018 expedition to Kiev. Only 1000 Pecheneg warriors supported the Polish ruler at that time. ${ }^{182}$ According to Rus' chronicles, during its second expedition against the Bulgarians, the Kievan prince's army consisted of 10,000 men. ${ }^{183}$ Experts on the subject consider this number reliable, and most likely refers to the Slavic-Varangian units led by Sviatoslav. ${ }^{184}$ The number of allied troops was probably no higher than half of this number, which, taking into account the fact that this also included the Magyars and Bulgarians, suggests that no more than 1,500 to 2,00o Pechenegs took part in Sviatoslav's expedition. Such a number was only a fraction of the mobilization potential of this ethnos.

This last finding provides a basis for two hypotheses for determining the nature and motivation of the Pechenegs' participation in the expedition of the Kiev Prince. The first one would assume the formation of an alliance between the Rus' and just one tribe among the nomads, that which had inhabited the western extremes of Patzinacia (tribe Giazichopon). This tribe may have already attacked Bulgaria earlier, which would have justified its participation in the Kievan expedition. In addition, it was peripheral in relation to other Pecheneg tribes, as well as being located far from the main Rus' cities, which meant it rarely threatened the centre of the Kievan state. Presumably it also did not take part in the invasion of 968 , so it was not at war with Sviatoslav. This cooperation with Giazichopon was important since it could protect the rear of the Rus' army. Byzantium could have tried to persuade the Pechenegs who lived near the Danube to carry out sabotage actions against the rear of Sviatoslav's army in Bulgaria. The alliance with this tribe prevented such a possibility.

However, there is also a second possibility, according to which the Pecheneg auxiliary unit would act as hostages, guaranteeing the neutrality of the Pechenegs during the Byzantine-Rus' war. The Primary Russian Chronicle describes Sviatoslav's victory in 968 in a brief passage:

He [Sviatoslav - A.P.] therefore collected an army, and drove the Pechenegs out into the steppe. Thus there was peace. ${ }^{185}$

\footnotetext{
182 Cf. Chapter 6.1. of the present book.

183 PVL 1, AM 6479 (971), col. 7 O.

184 Runciman 1930, 205 (note 4); Łowmiański 1973, 218. According to Leo the Deacon, 30,ooo 'Scythians' fought against 10,0oo Byzantines, commanded by Bardas Skleros, in the Battle of Arcadiopolis. The number of Sviatoslav's soldiers is probably overestimated. The forces of both sides, judging by the outcome of the battle, were probably equal, or the barbarians had a small advantage. LeoDiac., VI 12 (p. 109); Talbot, Sullivan 2005, 159.

185 PVL 1, AM 6476 (968), col. 67; Cross, Scherbowitz-Wetzor 1953, 86.
} 
However, if relations between the Pechenegs and Rus' had actually become peaceful, i.e., the nomads had ceased their attacks on Kiev, then driving the Pechenegs 'into the steppe' alone could not have been the main reason for this peace. Sviatoslav had most likely defeated his southern neighbours in 968 in a rather spectacular fashion, forcing them to agree to an alliance and provide auxiliary forces for the planned expedition. ${ }^{186}$ Only such a solution would have guaranteed the safety of Kiev. The alliances with Hungary and Bulgaria served similar purposes. Their participation in the expedition against Byzantium limited or even excluded the chance of diplomatic intervention on the part of Constantinople aimed at using these two ethne against Sviatoslav. The second hypothesis therefore seems to be more justified, as a forced alliance with the Pechenegs would have secured the rear of the Rus' forces. The promise of abundant spoils in the Balkans would certainly have helped overcome any doubts or objections. ${ }^{187}$

The second expedition began with a number of successes for the Rus', at least up until their defeat in the Battle of Arcadiopolis (970). Contrary to the accounts found in Byzantine historiography, which described the clash as a defeat for the barbarians, Sviatoslav's army was not completely crushed, but the Rus' prince was forced to stop his march on Constantinople. A fact of particular importance for our discussion is that in the first phase of the battle, the Byzantine troops managed to cause considerable losses among the Pecheneg forces. ${ }^{188}$ It is even possible that they was completely annihilated. Sviatoslav thus lost his hostages, which resulted in even greater anger and an increased desire for revenge among their kinsmen.

The further course of the war was unfavourable for Rus'. During the course of his brilliant campaign, Emperor John Tzimiskes forced Sviatoslav to withdraw to the Danube and take refuge within the walls of Dristra. After a long siege, and one final failed attempt to break through the ring of Byzantine troops in July 971, the Rus' ruler capitulated. ${ }^{189}$ John Tzimiskes forced his defeated opponent to accept harsh peace conditions, which, however, did

186 It is worth noting that Sviatoslav's behaviour is very similar to the behaviour of the commander Pesah towards the defeated Rus' forces led by Helgu, mentioned in the Schechter's Text. He ordered them to attack Byzantium, which was to be a form of reprisal for attacking the territory of the khaganate. Cf. above.

187 Some Bulgarian researchers find the participation of the Pechenegs in the second expedition as allies of Sviatoslav difficult to accept. They suggest that the nomads formed an alliance only with the Bulgarians. Cf. Dimitrov 2011, 237-238. Bozhilov 1973, 6 o.

188 Io.Scyl., 289-29o; Wortley 2010, s. 277; Io.Zon., 524-525; Trapp 1986, 33-34.

189 Ostrogorski 1967, 248-249. 
not exclude the possibility of further cooperation. Sviatoslav had to pledge to withdraw from Bulgaria and never return to the Balkans, to stop his attacks on Kherson, and provide military support to the Empire in the event of a conflict with a third country. In return, Tzimiskes renewed the trade privileges of Rus' merchants. ${ }^{190}$

It is significant that after the treaty was signed, the Archbishop (archiereus) of Euchaita, Theophilos was sent to the Pechenegs. His task was to renew the alliance with the nomads, which had been undermined by their forced alliance with the Rus' prince. As allies of the imperial court, the Pechenegs were told not to invade Bulgaria, which, since much of it had come under the direct control of the Byzantine Empire, was a reasonable demand. Theophilos also asked the nomads, on behalf of the Rus' ruler, to allow Sviatoslav to pass safely through their territory as he returned to his homeland. ${ }^{191}$ The Pechenegs agreed to fulfil all of the archbishop's requests with the exception of the last one, which clearly indicated their intentions towards the Kievan prince. ${ }^{192}$

Theophilos' mission seems to prove that the court in Constantinople intended to continue the policy towards the Pechenegs and Rus' formulated in the mid-1oth century by Constantine vir. Although Byzantine diplomats wished to maintain peaceful relations with Kiev, they were still concerned about the excessive growth of its power. Good relations with the inhabitants of the Black Sea steppe served as a factor in suppressing Rus' expansion. The events of 965-971 confirmed the possibility of a renewal of such a policy. However, the hostile stance of the nomads now provided Byzantine diplomacy with an important lesson, one that would most likely be long remembered. By denying Sviatoslav a safe return, the Pechenegs unequivocally stated that they did not intend to be an obedient tool of Constantinople. This observation most likely reduced the value of the nomads as a political partner in the eyes of the Byzantine elites. The fact that for the next nearly half-century (until 1017) there is no mention of any Byzantine-Pecheneg contact seems to confirm this hypothesis.

19 Io.Scyl., 309; Wortley 2010, 293; Io.Zon., 534-535; Trapp 1986, 40; PVL 1, AM 6479 (971), col. $72-73$.

191 Io.Scyl., 309-310; Wortley 2010, 293; Io.Zon., 535; Trapp 1986, 40.

192 Io.Scyl., 310; Wortley 2010, 293; Io.Zon. 535; Trapp 1986, 40. John Skylitzes clearly states that the Pechenegs became angry with the agreement concluded between Byzantium and Sviatoslav. The anger of the nomads was probably triggered by the fact that the Rus' ruler, who had caused them to get involved in a terrible war with the Empire, then made peace with it. Cf. Paroń 2oogb, 496-497. 
After the peace treaty, Sviatoslav embarked on his return to Rus'. Having ignored the warning of the voivode Sveneld, he decided to sail to Kiev on monoxyla canoes. However, at the rapids in the lower reaches of the Dnieper River, the Rus' ruler encountered Pecheneg forces, which forced him to stop his further journey and winter in Belobereg. Since his forces were not prepared for this stay, hunger undermined their strength and morale. ${ }^{193}$ In the spring of 972, Sviatoslav attempted to cross the rapids again. This time it ended in tragedy. The prince perished, along with the majority of his forces. Only the units commanded by Sveneld, who probably chose to travel on land, returned safely to Kiev. ${ }^{194}$

As in the case of the invasion of Rus' in 968, many scholars have tried to identify an external power that may have inspired this attack. It is quite commonly assumed, especially by Russian researchers, that it was the result of diplomatic efforts by the court in Constantinople. ${ }^{195}$ However, since this hypothesis contradicts the report of John Skylitzes about the mission of Archbishop Theophilos, it should be rejected. The Pechenegs planned the attack on Sviatoslav on their own. A desire for revenge, resulting from the failure of the Kiev expedition of 968 , as well as the death of their people in the Battle of Arcadiopolis, was most likely sufficient to make them attack an enemy they hated. Adding to these reasons was most certainly the fear of the Rus' state becoming even more powerful. ${ }^{196}$ Wilhelm Barthold, based on his analysis of numerous Muslim sources, once stated that the damage done by the forces of Sviatoslav in Khazaria had a profound impact on the Islamic world. ${ }^{197}$ It must have also made a significant impression on the nomadic neighbours of Rus', further intensified by the two expeditions to Bulgaria.

The victory of the Pecheneg ruler Kuria, who had killed Sviatoslav Igorevich, was the greatest and most spectacular victory by the nomads over the Rus' state. It provided proof that the Black Sea steppe were still their natural domain.

\footnotetext{
193 PVL 1, AM 6479 (971), col. 73-74.

194 LeoDiac., IX 12 (p. 157); Talbot, Sullivan 2005, 200; Io.Scyl., 310; Wortley 2010, 294; Io.Zon., 536; Trapp 1986, 40-41; PVL 1, AM 648o (972), col. 74.

195 Karamzin 1899, 181-182; Grekow 1955, 487; Levchenko 1956, 288-289; Pletneva 1958, 215; Tăpkova-Zaimova 1976, 35; Fine 1983, 187; Karpov 1997, 64-65; Kniaz'kii 2003, 32. Christo Dimitrov (2011, 240) assumes that Bulgarians, inhabitants of Little Preslav, inspired the murder of Sviatoslav. It should be admitted that this hypothesis has a stronger basis in the sources than claims about the alleged involvement of Byzantine diplomacy. Cf. Paron 20ogb, 495 .

196 Cf. Paron 20ogb, 494-499 (detailed analysis examining responsibility for the death of Sviatoslav Igorevich).

197 Bartol'd 1963, 688; Grekow 1955, 481.
} 
However, there were already indications foreshadowing the impending end of their rule in this region, as will be discussed in the next chapter.

For three quarters of the 1oth century, the Pechenegs had been an important element of political relations in Eastern Europe. This is evidenced by the fact that authors from distant lands noted their presence in the region. ${ }^{198}$ This ethnos played such an important role because of its considerable military potential as well as the fact that it occupied an area of strategic importance. In the 1oth century, the Black Sea steppe became a niche of sorts, encircled by political entities that for various reasons had interests in it and its inhabitants. One can hardly resist the impression that the Pechenegs were often quite passive in these political manoeuvrings and relied mostly on their instincts in their external relations. This was largely determined by their segmented and acephalic internal organization. This does not mean, however, that the nomads were merely tools to be used by neighbouring countries. Their relations with the Byzantine Empire demonstrate this very clearly. They were never clients of Constantinople, and became a lasting ally relatively late, i.e., early during the independent reign of Constantine Porphyrogenitus. This alliance most likely lasted until the death of the Emperor, that is, until the end of 959. Earlier, they cooperated only on an occasional basis (the attempt to use the nomads against Simeon in 917). It is difficult to say whether the Byzantine-Pecheneg alliance continued during the reign of Romanos II and Nikephoros II Phokas. It was clearly strained during the reign of John Tzimiskes, but soon, thanks to the mission of Archbishop Theophilos, it was restored. The murder of Sviatoslav, committed against the advice of the Constantinople emissary, however, clearly showed that the Pechenegs did not intend to obey the orders of the Emperor when they did not suit their interests. The relations of the nomads with other political powers were no different.

When they attacked Kiev in 968, or four years later when they murdered the Rus' prince, their actions were primarily motivated by their own interests. In the absence of hard source data, there is no justification for trying to prove the intervention of any external power, such as Byzantium or the declining Khazar Khaganate. The relationship between the Pechenegs and the khaganate in its

198 Apart from Mas'ū ūi, who considered the Pechenegs to be the most militant of the Turkic peoples, they are named by Ibrahim ibn Yaqub and Liutprand of Cremona as one of the most important ethne in south-eastern Europe. Cf. ibn Yaqub, 51, 52; Mishin 1996, 189, 19o; Liutprand., I 11 (p. 9). 
final years is unclear. The nomads most likely benefited from the trade contacts which had developed within the Pax Chazarica, but this does not prove their dependence on the Khazars. But the Pechenegs were not their enemies either. In 965, when Sviatoslav was destroying the foundations of the Khazar system, they most likely took a neutral stance. They were soon to suffer the consequences of their passivity. 